\title{
Strīkāmā vai gandharvāh. Spirit-possession, women, and initiation in Vedic India ${ }^{1}$
}

\author{
Per-Johan Norelius
}

Gothenburg, Sweden

\begin{abstract}
The nature of the Vedic gandharvas, and their female counterparts, the apsarases, has been the subject of much controversy. While often appearing in Vedic texts as a spirit of procreation, opinions have differed as to whether the pali gandhabba-, mentioned in the Buddhist Nikāyas as a being whose presence is necessary for the conception of a human being, should be understood in this light, or (following Buddhist commentarial tradition) as a disembodied soul entering the womb in order to reincarnate. The present study, opting for the first alternative, will explore the older, Vedic gandharva's nature not only as a genius of fertility and procreation, responsible for conception as well as miscarriage, but also as a lusty, potentially harmful spirit with a taste for mortal women - even married ones. The gandharva's (in post-RV texts usually in plural) desire for women sometimes expresses itself in his taking possession of mortal females; thus explaining text-passages where gandharvas are said to cause mental illness. This possession could however have positive aspects, as the
\end{abstract}

\footnotetext{
${ }^{1}$ I would like to thank professor emeritus Folke Josephson for reading a draft of this article, and for checking the references to ancient Iranian texts.
} 
gandharva could speak through the possessed woman and leave oracular answers on questions of esoteric and ritualistic matters. This belief, it will be argued, shows affinities to possession cults around the world, where the role as possessed oracle is frequently played by girls or women - a fact well-known from anthropology. But gandharvapossession must also be understood in the light of a conception of the gandharva as mediator between this world and the other; as a being with a knowledge of divine secrets, which he could impart to mortals in exchange for the enjoyment of their women. This same kind of exchange often appears in myths, such as that of the contest between gods and gandharvas for the soma and the goddess Speech.

In mythology, the gandharvas and apsarases are frequently depicted as youthful, good-looking, and fond of games and sports, music and dancing, and erotic activities. A case will be made for a connection between these beings and the adolescent period of life in Vedic society. In the domestic ritual, offerings are made to "the gandharva" by girls about to get married, thus asking for his permission; while young men who have completed their studies and are about to settle down and marry, are given a staff representing the gandharva, to "guard" them in their new life. All this suggests that the single gandharva of older Vedic times was thought of as a tutelary deity of unmarried adolescents, male as well as female (the latter being "married" to him). There are also instances in the priestly ritual where "young, beautiful" boys and girls impersonate the gandharvas and apsarases. Some sort of bond between these deities and people in the adolescent, pre-married stage of Vedic life (the prathama-vayasáor "first age-span"), is also suggested by the association of these beings with the sabha - described by some scholars as a "men's house" in the anthropological sense of the term - and with the vrātya or member of the Vedic "sodalities" of young men.

Keywords: spirit possession, Vedic religion, Mahābhārata, apsaras, soma, women, marriage ceremonies, rites of passage, Männerbünde.

\section{Early Buddhist gandhabba-}

A fair amount of the discussions around the beings of Indian mythology called gandharvas has tended to take as its point of 
departure a couple of comparatively late passages, found in the Buddhist Majjhima Nikāya. One of them, in the Assaläyanasutta (MN 2.156ff), appears in the context of a discussion, retold by the Buddha, between the seer Asita Devala and seven birth-proud brahmins, on the topic of class and birth. The passage may be rendered as follows:

[Asita Devala:] "But do you know, sirs, how the descent of the embryo takes place?"

[Brahmins:] "We do know, sir, how the descent of the embryo takes place. Here the mother and father are come together, and the mother is in season, and the gandhabba is present. With these three things thus having come together, the descent of the embryo takes place."

Next, Asita Devala asks the brahmins if they know what class this gandhabba might belong to:

[Asita Devala:] "But do you know, sirs, if this gandhabba is a nobleman, or a brahmin, or a commoner, or a serf?"

[Brahmins:] "We do not know, sir, if this gandhabba is a nobleman, or a brahmin, or a commoner, or a serf."

[Asita Devala:] "In that case, sirs, do you know who you are?"

[Brahmins:] "In that case, sir, we do not know who we are."

The lines quoted first appear almost verbatim in another sutta of the same Nikāya: the Mahātanhāsañkhayasutta (MN 1.265-266). Postcanonical Buddhist texts like the Milindapañha and the Divyāvadāna present similar readings, ${ }^{4}$ which are, however, easily recognized as being based on the MN passages. ${ }^{5}$ What, then, is the gandhabba (Sanskrit gandharva-) in these passages, and what exactly is its part in the process of conception? Buddhaghosa's commentary on the MN composed in the fifth century C.E., and thus much later than the text commented upon - explains the word as a being (eko satto) that,

\footnotetext{
${ }^{2}$ jānanti pana bhonto yathā gabbhassa avakkanti hotīti? jānāma mayam bho yathā gabbhassa avakkanti hoti. Idha mātāpitaroca sannipatitā honti. mātā ca utun̄̄ hoti, gandhabbo ca paccupațthito hoti. evam tịnnam sannipātā gabbhassa avakkanti hotīti. ${ }_{3}^{3}$ jannanti pana bhonto yagghe so gandhabbo khattiyo vā brāhmano vā vesso vā suddo vāti? na mayam bho, jānāma yagghe so gandhabbo khattiyo vā brahmano vā vesso vā suddo vāti. evam sante bho jānātha ke tumhe hothāti? evam sante bho, na mayam jānāma ke ca mayam homāti.

${ }^{4}$ Quotations in Haas 2004, pp. 32ff.

${ }^{5}$ Hillebrandt 1987, p. 184.
} 
"driven on by the mechanism of karman" (kammayantayantito), appears at the scene of conception and, as it seems, enters the womb of the female as an embryo. ${ }^{6}$ Buddhaghosa's interpretation is repeated in texts like Vasubandhu's Abhidharmakośabhāsya, while the Amarakośa and other classical Sanskrit dictionaries gloss the word with the distinctly Buddhist term antaräbhava-sattva-, a "being of the intermediate state", specifying that this means a being in the state between two incarnations, i.e., a deceased individual waiting to be born in a new reincarnation. ${ }^{7}$ This is, indeed, the meaning of the antarābhava- or "intermediate state" of learned Buddhist speculation. ${ }^{8}$

How are we to evaluate this younger tradition? Scholarly opinion on the matter has mainly been divided along two lines, between those who accept the traditional interpretation, and those who see no support for this in the older Pali texts, preferring instead to see the gandhabba here as a genius of procreation. Among the latter we find Lord Chalmers, who, without taking notice of the traditional interpretation, rendered the word as "presiding deity of generation" in his translation of $\mathrm{MN} ;{ }^{9}$ as well as the Pali Text Society's Pali-English Dictionary in its entry on gandhabba, which, referring only to $\mathrm{MN}$ and the Milindapañha, states that this being is "said to preside over childconception". ${ }^{10}$ The other line of interpretation seems to be by far the most widespread one. First, as it seems, put forward by Oldenberg ${ }^{11}$ and Windisch ${ }^{12}$, the view of the gandhabba as a disembodied being in between two incarnations has been accepted by a series of nameworthy scholars. ${ }^{13}$ It is thus argued that, while the MN does not explicitly describe the being as a deceased individual awaiting its next incarnation, the words paccuppatthito hoti ("is present") suggest that it is not merely a deity presiding over procreation, but is actually taking part in the act in some way; and further, Asita Devala's question to the brahmins, whether they know what class the gandhabba might have belonged to (which they don't), followed by

\footnotetext{
${ }^{6}$ Quoted by Wijesekera 1994a, p. 208 n. 164.

${ }^{7}$ Hillebrandt op.cit., p. 180.

${ }^{8}$ Cf. e.g. Wayman 2002, and the bibliography in Haas 2004.

${ }^{9}$ Chalmers 1926, p. 189.

${ }^{10}$ Rhys Davids \& Stede 1952.

${ }^{11}$ Oldenberg 1894, p. 249 n. 1.

${ }^{12}$ Windisch 1908, pp. 112ff.

${ }^{13}$ Wijesekera 1994a (1945), 1994b (1964); Wayman 2002 (1970); Keith 2007 (1925), p. 376 n. 1. Cf., more recently, Haas 2004.
} 
the question, "In that case, sirs, do you know who you are?", is seen as clear evidence that the gandhabba is the very being that is reborn (the brahmins not knowing what class they belonged to in their former lives). While acknowledging that early Buddhism had no concept of a transmigrating soul, a few scholars have sought to identify the gandhabbha with the consciousness, viññana-, which is elsewhere in the Nikāyas said to survive the destruction of the body and "descend" (ava-kam-) in a womb in order to be reborn. ${ }^{14}$

Assuming that this interpretation is correct, one important question remains: what connection, if any, is there between this Buddhist conception and the older, Vedic concept of the gandharvaconsidering that the belief in transmigration does not appear in Vedic literature until the early Upanișads, and is not even there in any way connected with the gandharvas? Those scholars who have addressed this issue have mostly pointed out the Vedic gandharva's function as a fertility deity, with a somewhat unclear connection to marriage and conception, and have seen the Buddhist notion as a development of these ideas, having been reinterpreted under influence of the transmigration doctrine. Keith, for instance, points to a well-known practice described in the Gṛhyasūtras: a newly-wedded couple should, for the first three nights following the wedding, abstain from intercourse, sleeping with a staff in the bed as a symbolic barrier between them. This staff is addressed as "the gandharva Viśvāvasu", the underlying idea apparently being that the wife during these three nights was in Viśvāvasu's possession. "This position of the Gandharva is clearly a relic of more primitive thought than that which makes, as a result of the belief in transmigration, the Gandharva the being which at conception enters the womb, and it is to this popular and ancient belief that we must look in the main for the choice of this name ${ }^{15}$ rather than (as does Windisch, Buddha's Geburt, pp. 13 ff.) to transmigration into a Gandharva." ${ }^{16}$ Similarly Hillebrandt, who provides much evidence for the gandharvas' being connected with fertility and generation; ${ }^{17}$ a subject to which we will return in some more detail.

\footnotetext{
${ }^{14}$ Wijesekera 1994a, 1994b. More tentatively Oberlies 2005, pp. $107 \mathrm{f}$.

${ }^{15}$ I.e., the designation of the being-to-be-born as gandhabba.

${ }^{16}$ Ibid.

${ }^{17}$ Hillebrandt 1987.
} 
Mention should also be made of the work of Pischel, ${ }^{18}$ who, writing before any of the above-mentioned authors, and apparently unaware of the traditional Buddhist interpretation of the MN passages, made an attempt to explain these in the light of Vedic beliefs. Interpreting the gandhabba of $\mathrm{MN}$ as a being entering the womb to become an embryo, Pischel made a detailed survey of the gandharvas in Vedic literature, seeking to prove that the concept there is basically the same as the early Buddhist one. Pischel even sought to establish an etymological connection between the words gandharva- and garbha-, "fetus"; an unhappy conjecture which he later seems to have rejected. ${ }^{19}$ While his attempts to equate gandharva- in obscure rigvedic passages with "fetus" appear untenable and do not seem to have won much acceptance even in his days, Pischel's study does, however, point out some passages from later Vedic texts that are of great interest in view of the alternative interpretation of gandharval gandhabba as "genius of procreation", mentioned above. Thus, the Pañcaviṃśa Brāhmana (19.3.2) advices someone who wishes for offspring to make an offering to the gandharvas and their female counterparts, the apsarases; for these beings preside over offspring. ${ }^{20}$ A similar idea seems to underlie a passage in the Śānkhāyana Gṛhyasūtra (1.19.2, = Kaușītaka Gṛhyasūtra 1.12.2), which, describing the garbhädhāna- or sacrament for begetting offspring, has the husband touch the wife's genitals with the words, "You are the mouth of the gandharva Viśvāvasu", ${ }^{21}$ before uniting with her. The Pañcavimśa Brāhmaṇa passage is especially clear as regards the role of the gandharvas in procreation: they "preside over a man's offspring or childlessness" (manusyasya prajāyā vāprajastāya veśate) - they are not, as Pischel and others have suggested, the germ of that offspring.

An exhaustive criticism of the (re-)incarnation theory was presented by Hillebrandt ${ }^{22}$ in an article that, however, appears to have been strangely overlooked in most discussions. Hillebrandt points out the total lack of evidence for a belief in the gandharva's descending into the womb at conception, both in the brahmanical traditions and in

\footnotetext{
${ }^{18}$ Pischel \& Geldner 1889, pp. 77-90.

${ }^{19}$ Hillebrandt, p. 180.

${ }^{20}$ Pischel in Pischel \& Geldner, p. 78.

${ }_{21}^{21}$ gandharvasya viśvāvasor mukham asi.

${ }^{22}$ Hillebrandt 1987 [first publ. 1906].
} 
Buddhist texts not based on those discussed. Although the gandharva/gandhabba plays a rather prominent part in brahmanical as well as Buddhist mythology, it is nowhere else said to be a discarnate spirit awaiting its next incarnation. Remarkably, the numerous discourses on transmigration and karman in the Pali and later Buddhist texts do not include the gandhabba in the role of a being in a state between two incarnations. ${ }^{23}$ Hillebrandt summarizes:

Es ist also gegenüber der gesamten Literatur und den Kunstzeugnissen eine verschwindende Anzahl von Stellen, die für diese absonderliche Bedeutung von gandharva eintreten. Die Stellen im Majjh. Nikāya, Assalāyanasutta und Divyāvadāna sind sehr ähnlich und scheinen ein freies Zitat zu sein, das aus einem älteren Text entlehnt ist. Im Assalāyanasutta soll bewiesen werden, daß zwischen den verschiedenen Kasten kein wesentlicher Unterschied bestehe ... Es ist nun keineswegs ausgemacht, daß ,der Faden der Argumentation, wie Oldenberg meint, ${ }^{24}$ total zerschnitten würde', wenn wir Gandharva hier als einen Genius der Fruchtbarkeit ansehen wollten, der ja ebenfalls keiner Kaste angehören würde..${ }^{25}$

Rejecting, thus, the view of the gandhabba in $\mathrm{MN}$ as a spirit entering the womb, Hillebrandt identifies the Milindapañha passage as the earliest text expressing this belief; it must, he suggests, have been composed when the MN passages (which it quotes) were no longer fully understood, and the ancient conception of the gandharva as a fertility deity had become obsolete. "Mir scheint daher, daß die Auffassung der Milindapañho nichts anderes ist als ein Mißverständnis brahmanischer Mythologie.,"26

I agree with Hillebrandt's conclusions. A close look at the contexts of the two MN passages raises serious objections to the traditional interpretation of these. We will first discuss the one in the Mahātaṇhāsankhayasutta, which has not received as much comment as the passage in the Assalāyanasutta. What is the context that makes the Buddha bring up the topic of procreation, including the gandhabba, in this sutta? The reason for his entire sermon here is the heretical view propagated by a certain monk, who holds that a transmigrating being is constituted by one and the same consciousness

\footnotetext{
${ }^{23}$ Ibid. pp. $181 \mathrm{ff}$.

${ }^{24}$ Apparently referring to Oldenberg 1894, p. 249 n.

${ }^{25}$ Ibid. pp. $184 f$.

${ }^{26}$ Ibid. p. 186.
} 
(viñ̃̃annam), which enters ever new bodies. This view being completely incompatible with the Buddhist "no-self" doctrine, which denies any lasting soul or essence that transmigrates, the Buddha forcefully rejects the monk's belief, demonstrating how an individual is actually a conglomerate of numerous constituents, put together by various causes. The sermon mainly consists of an exposition of the "conditioned arising" (paticcasamuppāda-), the chain of causes responsible for the rebirth and formation of an individual. At the end, this teaching is illustrated with an exposition on how these causes work in a person's life, beginning with conception; and it is here that we find the passage on the gandhabba. The entire sermon is, thus, intended to reject the theory of a transmigrating being; each individual creature is the result of numerous causes - among which we find "the three things" facilitating conception: the parents, and the gandhabba.

The case is similar with the Assalāyanasutta. While, as we have seen, Asita Devala's question as to the social class of the gandhabba has been seen as confirming the theory of an incarnating spirit, Devala does, in fact, question the brahmins in a similar vein on the social class of their mothers, fathers, and ancestors: do they know if their mothers have been only with their (brahmin) husbands, or their fathers only with brahmin women? Or if their mothers' mothers, and fathers' fathers, seven generations back, have only been with men or women belonging to the same class? And, finally, do they know the class of the gandhabba, the third cause (after the parents) of their conception? The entire discourse is meant to humble the haughty brahmins, who consider their own class the very highest.

Finally, some words should be said on the "hopelessly confused" ${ }^{27}$ presentation in the Milindapañha. ${ }^{28}$ While even Hillebrandt acknowledged that this text connects the gandhabba with rebirth, its account is remarkably dissimilar from the later ones, which identify the gandhabba as a being of the "intermediate state". Instead, we appear to be facing two different definitions of the word in this text, as it attempts to clarify the old $\mathrm{MN}$ passage. We are given a description of how "a certain gandhabba, coming from somewhere or else", ${ }^{29}$ enters a womb (yoni-) in a family of some species (egg-born,

\footnotetext{
${ }^{27}$ Wijesekera 1994a, p. 196.

${ }^{28}$ Trenckner's ed., pp. $123 \mathrm{ff}, 128 \mathrm{ff}$.

${ }^{29}$ yo koci gandhabbo yato kutoci āgantvā.
} 
"sweat-born" etc.). The being is not specified to be a spirit between two incarnations, and the phrasing suggests an uncertainty on the part of the author as to the gandhabba's sphere of origin. This is markedly different from the later account of Buddhaghosa, who has the gandhabba take birth "driven on by the mechanism of karman"; in fact, the Milindapañha does not expressly mention re-birth at all in this context. The cause of the gandhabba's taking birth in some species or another is said to be kulavasena, "by the power of family [or 'species']", perhaps implying that the gandhabba is attracted to various kinds of species; ${ }^{30}$ in any case, this is expressly different from birth caused by karman - kammavasena - which is only one of four ways in which the "descent of the embryo" might take place. The birth caused by kulavasa- is the only one of these explicitly involving the gandhabba. ${ }^{31}$ All this suggests that the integration of the gandhabba into the transmigration doctrine took place successively, long after the composition of the Nikāyas. This holds especially for its being identified as a being of the "intermediate state" (antarābhava-), a concept which, though fairly ancient, first appears as a topic of the doctrinal disputes of post-canonical Theravāda Buddhism. ${ }^{32}$

\section{The Vedic gandharva as a procreation-divinity}

Now, there are clear indications of a connection between gandharvas and fertility in older, Vedic literature; not least in the spells and

\footnotetext{
30 "If, thus, the gandhabba, coming from somewhere or else, appears in an eggborn family, he becomes eggborn. If, thus, the gandhabba, coming from somewhere or else, appears in a placenta-born family, he becomes placenta-born." (The same applies to "sweat-born" etc.) (yadi tattha gandhabbo yato kutoci āgantvā andaje kule uppajjati, so tattha andajo hoti. yadi tattha jalābuje yato kutoci āgantvā jaläbuje kule uppajjati, so tattha jalābuje hoti.)

${ }^{31}$ In the case of birth caused by prayer (āyācanavasena; p. 129), a deity (devaputta-) is sent down from heaven by Sakka to take birth in a virtuous family "with many offspring but no sons"; the "deity" does not, however, seem to be identical with the gandhabba.

32 Only after finishing the above discussion did I come upon the important work of Langer (2000), whose first chapter deals with the problem of the gandhabba. Langer's conclusions come close to ours: the gandhabba is deemed to be an ancient spirit of procreation, as evinced by Vedic texts, and the stereotyped formula in the Pali texts is, suggests the author, drawn from popular beliefs or sayings. In later times, it was no longer understood and had to be reinterpreted.
} 
incantations of the Atharvaveda. In AV 4.4 (Śaunaka recension), the gandharvas are mentioned as having restored the virility of the god Varuṇa by means of a "penis-erecting herb" (óṣadhi- śepahárșaṇi-, v. 1). An association with virility seems again implied in 4.34.2-4; verses with the purpose of making sure that deceased men will not dwell in the next world bereft of their virile force, but will be able to indulge fully in the celestial pleasures awaiting them. "Jătavedas [the cremation fire] burns not their male organ; in the heavenly world, lots of women-folk are theirs", ${ }^{33}$ says v. 2, and the second half of the next verse states about the dead person that he "stays with Yama [the god of the dead], goes to the gods, revels with the soma-drinking gandharvas" (transl. Whitney, slightly modified). ${ }^{34}$ The notion of the gandharvas as "reveling" ( $m a d-$ ), often together with the apsarases, recurs several times in AV, as we shall see, and probably has some erotic implications; in light of v. 2, it would seem that the dead man partakes of the same kind of pleasures, and this seems to be confirmed by the next verse (v. $4 \mathrm{~b}$ ), which carries on the theme of preserved virility in stating of the dead men that "Yama robs them not of their seed (retas)". ${ }^{35}$ Though not actually bestowing virility in these verses, the gandharvas clearly appear as associated with it; indeed, as these beings do not usually appear in the heaven of the dead, their mention here seems to be facilitated exclusively by their typical indulgence in sensual - especially erotic - pleasures. The same association with virility no doubt underlies the offering, at the aśvamedha-sacrifice, of the penis of the sacrificial horse to the gandharvas (and the testicles to the apsarases) as prescribed in TS 5.7.15; as well as the term mürdhanvām̆s ... gandharvah, "the gandharva with the head", used in a wedding hymn as, apparently, a designation for the penis. ${ }^{36} \mathrm{~A}$

\footnotetext{
${ }^{33}$ náișām șiśnám prá dahati jātávedāh svargé loké bahú stráinam eșām.

${ }^{34}$ áste yamá úpa yāti devấnt sám gandharváir madate somyébhih.

${ }^{35}$ Transl. Whitney (in Joshi 2004), slightly modified. (náinān yamáh pári muṣnāāti rétah.)

${ }^{36}$ The hymn is found in the Kāthaka Gṛhyasūtra 25.23; parts of it are quoted in other sūtras (Caland 1929). Mürdhanvant is also found as a name in the list of gandharvas in Taittirīya Āranyaka 1.9.3 (cf. ibid., p. 309). Of interest in this context is also the derivation of Kandarpa, a name of the god of love in later mythology, from gandharva-, proposed by Barnett (1928, p. 704 n. 2), who states: "I would explain Kandarpa as a Prakrit form of Gandharva. In some of the vernaculars classed together by the grammarian as 'Paiśācì', particularly the Drāviḍī, the word gandharva
} 
fertility function also seems implied in the offering of three measurements $(m \bar{a} t r \bar{a})$ of grain to the gandharvas at harvest in $\mathrm{AV}$ 3.24.6; a connection with vegetation is echoed in some younger texts. ${ }^{37}$ In some Middle Vedic texts, we find the gandharvas and, especially, the apsarases expressly associated with sexual intercourse (mithuna-): ŚB 8.6.1.21, 9.4.1.4; JUB 3.25.8.

The connection with procreation and birth, whatever be its exact nature, is thus a recurring theme in the Vedic depiction of the gandharva. The designation, in a wedding hymn, of the penis as "the gandharva with the head", and, at the rite for conception, of the wife's genitals as the mouth of Viśvāvasu (implying an identification of the gandharva with the womb, or perhaps locating him inside it?), are clearly late echoes of the same kind of conception as encountered in some AV hymns. It may be noted that the notion of a deity responsible for placing and protecting the embryo inside the womb (if something like that is indeed the function of the gandharva/gandhabba) is not foreign to later Indian mythology, where we find Naigameșa or Nejameșa filling this function. ${ }^{38}$

The Vedic gandharvas and apsarases have an ambivalent relationship to marriage and wedding-ceremonies. We have already mentioned the staff representing Viśvāvasu, which is placed between the newly-wedded couple during the three nights of abstention. As Slaje has shown, ${ }^{39}$ this custom - including the three nights of celibate - is not to be found in early Vedic literature, appearing first in the Gṛhyasūtras. ${ }^{40}$ It does, however, have older precedents. Middle Vedic texts tell us that the wife was in a state of impurity not only during her period, but also for the first three days following it; no intercourse was

might either become directly kandarpa, or first change to kandappa and thence by a false etymology from darpa be sanskritised into kandarpa."

${ }^{37}$ In Vādhūla Śrautasūtra 4.116, the gandharvas and apsarases are connected with draught-oxen and ploughs, respectively, because "these gandharvas and apsarases generate food (i.e., crops)" (ete gandharvāpsarasa evānnam janayanty). (Text in Caland 1928, p. 237.) ŚB 11.2.3.9 mentions the gandharvas Yavamān ("possessing barley"), Uddālavān ("possessing uddāla-grain") and Antarvān ("pregnant"), as connected with winnowing baskets, agriculture, and grain, respectively. Cf. possibly JB 3.226, where the "Sväśira apsarases" are identified with the herbs (oșadhayah).

${ }^{38}$ So already in RVKh. 4.13.1, and some Grhyasūtras; see Winternitz 1895.

${ }^{39}$ Slaje 1997.

${ }^{40}$ For the practice - the so-called caturthikkarman - cf. in general Kane 1974, pp. 202ff; Pandey 2002, pp. 222ff; Gonda 1980, p. 394. 
to take place during this period, but only on the fourth night, after the wife had changed her soiled garment. The first time of cohabitation thus occurred as soon as the wife was clean from menstrual impurity; not after a specific number of nights following the wedding. ${ }^{41} \mathrm{~A}$ similar practice is, furthermore, prescribed for the newly initiated Veda-student, who had to spend the first three days after initiation in penance, eating non-salted food (so also the newly-wedded couple) before being fit to learn the Sāvitrī mantra. ${ }^{42}$ The concept of three "dangerous" nights, with suspension of certain activity, was thus an integrated part of certain Vedic rites of passage. There is no mystery about how this practice came to be included also in the rites of marriage and procreation; what has to be answered is rather how Viśvāvasu came to be a fundamental ingredient of the rite - neither he nor any other gandharvas having any part in the older practice. Presumably the notion of Viśvāvasu and the use of the staff were added fairly late to the practice, as some Gṛhyasūtras do not include either in the prescription of three nights' sexual abstention; ${ }^{43}$ where the staff appears but Viśvāvasu is not mentioned, ${ }^{44}$ the prescription that the staff be smeared with perfume (gandhalipta-) has, however, been interpreted as a reference to the gandharva; ${ }^{45}$ the frequent association of these beings with fragrance (gandha-) being due to the traditional etymology of the word gandharva-.

\footnotetext{
${ }^{41}$ The Gobhila Grhyasūtra (2.5.8) still prescribes the end of menstrual impurity as the time for cohabitation, besides this mentioning the three nights of abstention as an alternative being prescribed by "some" (7: eke).

${ }^{42}$ Slaje thus rejects the theory of an Indo-European origin of the marriage practice; for the use, in legends and in actual practice, of a stock or a sword as a symbolic sexual barrier between a sleeping couple, cf. e.g. West 2007, pp. 436-37.

${ }^{43}$ E.g. Pāraskara Gṛhyasūtra 1.8.21; Jaimini 1.22; Śānkhāyana 1.17.5ff.

${ }^{44}$ Āpastamba Gṛhyasūtra 8.9; BGS 1.5.16ff.

${ }^{45}$ E.g., Oberlies 2005, p. 103. Oberlies (ibid., n. 26) expresses doubt as to the connection with this staff and the one given to the snattaka or Veda student who has completed his studies and is about to return home - this staff, too, being addressed as "Viśvāvasu"; the identification is, according to Oberlies, "nicht unproblematisch", as the snātaka's staff is said to be vainava-, made of bamboo, while the one used during the nights of chastity is to be made of udumbara. While it may be true that this is not unproblematic, the identification of both staffs with Viśvāvasu can hardly be considered a coincidence. It is possible that the snataka's staff, being mentioned in Gṛhyasūtras which do not yet know the marriage custom (Jaimini 1.19; Gobhila 3.4.27), belongs to the older practice, and has been borrowed into the marriage rites; but what its original meaning was, is far from certain.
} 
The most common, and likely, interpretation of the practice is that the wife during these three nights "belonged to" Viśvāvasu. ${ }^{46}$ While the rite is late, the notion of Viśvāvasu claiming his rights to the newly-wedded woman appears very clearly already in RV and AV. In the "wedding hymn" RV 10.85, two verses (21-22, = AV 14.2.3-4) are directed to Viśvāvasu, imploring him to go away from the bride:

Rise up from here - for this one has a husband! I worship Viśvāvasu with obeisance and words of praise. Seek another one, dwelling in her father's house, [though] mature; that is your share by birth - seek it out!

Rise up from here, Viśvāvasu! We worship you with obeisance. Find another, attractive one; let the wife unite with her husband! ${ }^{47}$

More light on the nature of the relationship between Viśvāvasu and the bride is thrown by the verses $40-41$ :

Soma knew you first, the gandharva knew you next; Agni was your third husband; the fourth one is of human birth.

Soma gave you to the gandharva, the gandharva gave you to Agni; Agni has given me wealth and sons, and now this [wife]. ${ }^{48}$

Agni, the fire god, is here clearly the nuptial fire; ${ }^{49}$ the gandharva thus possessed the bride until the performance of the nuptial ceremonies. Viśvāvasu is now implored to seek another woman, who is still living with her father (pitrșádam ${ }^{50}$ ). The same conception of Viśvāvasu is found in the Atharvaveda; AV 14.2.33ff implores him, partly with words echoing those of RV 10.85, to go away from the bride and seek out a girl living with her father (v. 33), or return to the apsarases -

\footnotetext{
${ }^{46}$ See for example Keith 2007, pp. 375-76.

${ }^{47}$ úd ìrșvátah pátivatī hy èșá viśvá̀vasum námasā gīrbhír ịle / anyám icha pitrsádam vyàktāạ sá te bhāgó janúșā tásya viddhi // úd ìrșváto viśvāvaso námaseḷa mahe tvāa / anyám icha prapharvyàm sám jāyám pátyā srja /l.

${ }^{48}$ sómah prathamó vivide gandharvó vivida úttarah / tritìyo agnís te pátis turìyas te manuṣyajắn // sómo dadad gandharváya gandharvó dadad agnáye / rayím ca putrámịs cādād agnír máhyam átho imấm //.

${ }^{49}$ E.g., Oberlies 2005, pp. 101-102.

${ }^{50}$ The meaning of this word being uncontroversial, I see no reason for seeing, with Vasilkov (1990, p. 395 and n. 6), the first member pitr- as meaning the Ancestors, and the compound as referring to a Männerbund whose members, called gandharvas, represent or impersonate the spirits of the dead.
} 
"those are your kin" (tấs te janitram, v. 34); "go away toward your wives, the apsarases" ('bhí jāyáa apsarásah párehi, v. 35). The gandharva, whose lustful nature we are going to explore, has had legitimate claims to the woman before her marriage, but may not give up those claims even after the ceremonies, and has to be made to leave with implorations and spells. ${ }^{51}$ The notion of the gandharva's right to unmarried girls may underlie a rite prescribed in the KGS, according to which a girl reaching puberty, and thus becoming marriageable, is to perform a worship that in some way involves gandharvas (and a feminine Gandharvān $\bar{\imath}) ;{ }^{52}$ the gandharva is also included among the deities to which a young girl sacrifices before leaving her parents' house to get wedded (Śānkhāyana Gṛhyasūtra 1.11.4); similarly at KGS 17.1, where "Viśvāvasu the king of gandharvas (gandharvarāja)" appears at the end of a list of mostly abstract deities (e.g. Kāma, Bhaga, Hrīe Śñ̄, Lakșmī, Pușți), to whom offerings are made at the giving away of a girl for marriage. It appears that the girl, upon entering adulthood and a married life, had to propitiate the gandharva, to whom she had previously belonged. When Viśvāvasu or the gandharvas and apsarases in general are worshipped at wedding rites ${ }^{53}$ we may be dealing either with the same kind of belief, or simply with the old association with fertility.

${ }^{51}$ This is still the case in Brhadāranyaka Upanișad 6.4.19, a text which is in all likelihood older than any of the Grhyasūtras; here, in the context of the rites for begetting offspring, Viśvāvasu is asked to go away with (a variant of) the verse RV 10.85.22, no reference being made to any preceding nights of chastity.

${ }^{52}$ KGS 19-20. It is not very clear what is meant when the girl is admonished to lit two fires gandharve devakule vā, "in/at a gandharva or a shrine" (19.3). According to Devapāla's commentary, the gandharva- here is a place where water flows without cause (nimitta-); if so, the connection with gandharvas might be due to their association with water (for which see below). "Gandharvāṇī" in 20.2 is invoked with two other deities whose name are but feminized versions of those of male gods Indrāṇī and Varuṇāni - and may conceivably be based on the male gandharva of an older version of the rite.

${ }^{53}$ Cf. Joshi 1977, pp. 37-8, 48-9. In KGS 25.30, 35, describing the marriage ceremonies, the "maiden" (kanyā), is said to have sacrificed to Aryaman, the old Vedic god of marriage, and to the gandharva- pativedana-, "gandharva knowing/finding the husband"; as the offerings to the two deities are described in more or less identical words, and closely following each other, they appear to fill similar functions. The maiden's words, "May that divine gandharva release us (me) from here; not from that dwelling" (25.35: so 'smān devo gandharvah preto muñcātu māmusya grhebhyah; similarly of Aryaman, 25.30), obviously are a prayer for leaving the parents' house for that of the husband. (Aryaman pativedana- is addressed with 
AV 4.37 is a spell for warding off a menacing gandharva, who appears to be approaching a (married?) woman. The general tone of the spell is considerably more violent than the pleadings of RV 10.85 and AV 14.2; the gandharva appears as a more explicitly demoniacal being, ${ }^{54}$ and the words used to chase him off are forceful, even describing the physical injuries their magic inflicts upon the lustful demon. Though the spell has been considered yet another series of protective formulas used against the wife-coveting Viśvāvasu, I think this is doubtful; the gandharva is nowhere called Viśvāvasu, nor is there any reference to a recent wedding. The underlying conception may simply be the gandharvas' lust for women, wedded or not. ${ }^{55}$ Parts of the spell will be quoted:

similar words in AV 14.1.27-8.) Of interest are also some words uttered by the husband in connection with the first sexual intercourse of the newly-married couple (variants in KGS 29.1; Hiranyakeśi-Gṛhyasūtra 1.7.24.6): "The (magic charm of) concord that belongs to the cakravāka birds, that is brought out of the rivers, of which the divine Gandharva is possessed, thereby we are concordant" (transl. Oldenberg 1886, vol. 2 p. 198 [transliteration modernized]: cākravākam samvananam yan nadībhya udāhrtam / yad yukto devagandharvas tena samvaninau svake). In all these texts, the gandharva is invoked to grant a (happy) marriage. Finally, the Āgniveśya Gṛhyasūtra, 2.5.61ff, includes a nuptial litany in which various Vedic deities and forces are identified with the gandharva (sing.) and his apsarases.

${ }^{54}$ The gandharvas here are mentioned together with rákșases (1-2) and piśācás (10); likewise in AV 11.9.16, 12.1.50. Kuiper (1996, p. 246 ) sees the "original" gandharva as a comparatively benign creature, and holds the lofty rgvedic gandharva (see below) to be an older conception than the menacing being seen in the AV; the possibility that this contrast has to do with different "genres" is considered, but rejected. Instead, Kuiper suggests "that a foreign influence has contributed to a 'demonization' of the Gandharvas, in that a group of non-Aryan demons was grafted upon the Gandharva", but concedes that "this cannot well be connected with the fact that Rig-vedic references to Indra's slaying the Gandharva [...] are only found in the Kanva book VIII" (ibid.). Judging from the Iranian parallels (for which see below), this might actually be the oldest conception of the gandharva. Personally, I believe that the gandharva was an ambiguous creature - neither god nor asura - who could appear in a positive function (as an intermediary between heaven and earth), but also carried darker characteristics (lustfulness, jealousy; causing insanity or miscarriage).

${ }^{55}$ Kuiper's statement (1996, p. 253), "It is obvious that this charm was pronounced three days after the wedding, when the Gandharva(s) had to be expelled," cannot be accepted in consideration of what we now know about the development of this practice (I refer to the study by Slaje). Perhaps Wijesekera (1994a, p. 190) is more correct in stating that "the reference is to the gandharva's power of 'possessing' human beings and causing madness rather than to their general connection with women". 
May the apsarases go to the river, to the ford of the waters [...]. Gulgulū, Pīlā, Naladī, Aukșagandhi, Pramandan̄̄ - go away thither, apsarases; you have been recognized!

Where there are fig-trees, banyans, huge trees with crowns - go away thither, apsarases; you have been recognized!

Where your swings, golden and silvery, are, and where cymbals and lutes sound jointly - go away etc.

$[\ldots]$

Of the hither-dancing, crested gandharva, husband of the apsarases, do I crush the testicles, I tear off (?) the penis ...

One like a dog, another like a monkey, a boy all hairy - having become pleasant to behold, the gandharva goes after women. Him do we make disappear from here with a potent spell.

The apsarases are your wives; you gandharvas are their husbands. Hurry off, immortal ones; don’t go after mortals! $!^{56}$

The notion that the gandharvas are by nature ugly, but take on beautiful forms in order to seduce women, is very unusual; elsewhere, only their famed beauty is referred to. ${ }^{57}$

${ }^{56}$ nadìm yantv apsaráso 'pám tārám avaśvasám/ gulgulūh pìlā nalady àukșágandhih pramandanìl tát páretāpsarasah prátibuddhā abhūtanal/ yátrāśvatthá nyagródhā mahāvrkșáh śikhandịnah/ tát páretāpsarasah prátibuddhā abhūtanal/ yátra vah pren்khà háritā árjunā utá yátrāghātăh karkaryàh samvádanti/ tát páretāpsarasah prátibuddhā abhūtanal/ [...\} änŕtyatah śikhandịno gandharvásyāpsarāpatéh/ bhinádmi muṣkà̃v ápi yāmi śépaḥ/l [...] śvéváikah kapir iváikah kumārạh sarvakeśakáh/ priyó drśá iva bhūtvá gandharváh sacate stríyas/ tám itó nāśayāmasi bráhmaṇā vīryà̃vatā //jāyáa id vo apsaráso gándharvāh pátayo yuyám/ ápa dhāvatāmartyā mártyān má sacadhvam//. (4.37.2-5, 7, 11-12.)

${ }^{57}$ For example, the gandharvas and apsarases are represented at the horse sacrifice by "beautiful" ('sobhanāh) young boys and girls (ŚB 13.4.3.7-8); they are elsewhere associated with gandha-, "fragrance" (due to etymologizing), and rūpa-, "shape, beauty" $(9.4 .1 .4 ; 10.5 .2 .25)$, "whence if any one goes to his mate he cultivates sweet scent and a beautiful appearance" (9.4.1.4, tr. Eggeling). In the epics and in early Buddhist texts, the beauty of the gandharvas is a common motif; the handsomeness of the gandharva king Citraratha is proverbial (cf. Hopkins 1915, pp. 156-57). Their fondness of garlands, ornaments and fine clothes (ibid.) is notable, and may be traced to Vedic beliefs; cf. TĀ 3.10 .3 (gandharvāpsaräbhyah sragalaṇkaraṇe) and perhaps already the celestial gandharva of RV 10.123.7, wielding bright weapons and clothing himself in a scented garment "to look like the sun" (drśé kám svàr naá). Apparently, the gandharvas and apsarases have elaborate hairdresses, a topic which will be discussed later. Lastly, it may be mentioned that the gandharvas are quite often 
The gandharvas and apsarases, dwelling in trees, are also implored not to harm a wedding procession, and specifically not the bride (AV 14.2.9). The lascivious nature of these beings is a cause of fear, but is also befitting deities of fertility and procreation. There is, thus, no actual contradiction when the Śānkhāyana Gṛhyasūtra 1.19.12 , describing the sacrament for begetting offspring, implores Viśvāvasu to go away (with the verse RV 10.85.21, quoted above), only to invoke him again as the actual act is about to take place: "You are the mouth of the gandharva Viśvāvasu", says the husband as he touches the wife's private parts. While the gandharva's desire for the wife is feared, his powers are nonetheless invoked (as it seems) for successful procreation. ${ }^{58}$ The lust for women is a common theme in Middle Vedic literature, where the gandharvas are given the epithet strik âma- (to be discussed later on). In the law-texts of later times (the Dharma Sūtras and -Śāstras), the "gandharva marriage" appears in the canonical list of eight forms of marriage, as a union based on love or

likened to the sun in splendor; besides RV 10.123.7, we have a "sun-hued" (súryatvag) gandharva in AV 2.2.2; a gandharva named Sūryavarcas ("having the splendor of the sun") is mentioned in Baudhāyana Śrautasūtra 18.46 and TĀ 1.9.3, and in the Mbh (Hopkins, p. 153); the gandharvas Citraratha and Vasuruci share the patronymic Sauryavarcasa- in AV 8.10.27, and the wedding hymn of KGS has (v. 14) an apsaras Süryavarcasinī, surely to be identified with Suriyavaccas a, daughter of the gandhabba Timbarū and lover of Pañcasikha, in the Dīgha Nikāya 2.263. When speaking of her five "gandharva husbands" (see below), Draupadì repeatedly uses the adjective surryavarcasa- for them (Mbh 4.15.33; 21.15), suggesting that this was a standing description of gandharvas.

${ }^{58}$ If, as the commentarial literature claims, the gandha-smeared staff represents the gandharva even in texts where Viśvāvasu is not mentioned, then the procedure laid down in BGS 1.5.17ff is of great interest; after the husband and wife have spent three nights in chastity with the staff placed between them, the husband lifts it up with the words, "From nourishment, from the earth are you sprung, o Tree; grow with a hundred shoots! ..." (ürjạ prthivyā adhyutthito 'si vanaspate śatavalśo viroha). $\mathrm{He}$ then hands it over to the wife with the words, "I unite you with offspring, like the surā-drink with māsara-!" (prajayā tvā samsrjāmi māsarena surām iva). The wife takes it, saying, "May I have offspring!" (prajāvatī bhūyāsam); then hands it back to the husband with words wishing him to obtain offspring and cattle (a wish repeated by the husband). It is obvious that the staff is invested with powers of fertility; it is, furthermore, to be made of udumbara-wood, which in Vedic ritual is frequently connected with fertility and abundance. Cf. also the commentaries on Āpastamba Gṛhyasūtra 8.9, where Haradatta states that the staff should be made from "a tree rich in sap" (kșirivrkșodbhavah), while Sudarśana specifies that the wood should be from a banyan, an udumbara, an aśvattha or a plakșa, since "these are the homes of the gandharvas and apsarases" (ete vai gandharvāpsarasām gṛhāh; quoting TS 3.4.8.4). 
desire, disregarding societal conventions; it therefore belongs to the four "lower" forms of marriage, which are forbidden to brahmins. ${ }^{59}$

AV 8.6 presents us with a much more harmful aspect of the gandharvas in relation to offspring. This is a spell against creatures causing miscarriage. In 8.6.19, at least some of them are identified as gandharvas:

They who $[\ldots]$ cause the [new-]born ones to die; who lie next to the birthgivers - may the Yellowish one (a talisman?) drive the womenenjoying ${ }^{60}$ gandharvas away, like the wind a cloud. ${ }^{61}$

The direct cause of the miscarriage is the cohabitation of the gandharvas with the pregnant woman; their lust for women may thus have sinister consequences. ${ }^{62}$ While demons causing miscarriage are a common feature in Vedic as well as later Indian mythology, ${ }^{63}$ the explicit reference to the gandharvas as strî́bhāga-, enjoying or partaking of women, definitely connects the passage under discussion to the general mythology around gandharvas, who are, in somewhat later Vedic texts, described as strīkäma-. The potentially harmful nature of their relationships with mortal women ${ }^{64}$ is also made clear in

${ }^{59}$ Cf. e.g. Kane 1974, pp. 516-523.

${ }^{60}$ Lit. "sharing in women".

${ }^{61}$ yé amnó jatấn māráyanti sûtikā anusératel stríbhāgān pingó gandharvấn vấto abhrám ivājatul/.

${ }^{62}$ This is not surprising, considering the often dangerous influence of similar semidivine beings; cf. Winternitz 1895, pp. 154-55, who, commenting on Nejameșa, notes "how closely connected the two ideas are of a deity dangerous to children, and a deity helpful in the procreation of children".

${ }^{63}$ Note already the short hymn RV 10.162, imploring Agni the Slayer of Demons (raksohan-) to chase away an incubus hurting the embryo inside the womb; the sexual aspect is brought out clearly in v. 4: "Who separates your thighs, [who] lies between the married couple; who licks the inside of the womb - him do we make disappear from here." (yás ta ūrú viháraty antarấ dámpatī śáye / yónim yó antár ārélhi tám itó nāsayamasi //) In 5-6, the demon is said to lie down with the woman, having assumed the form of her brother, husband, or lover, or after having overwhelmed her with sleep.

${ }^{64}$ Kuiper (1996, p. 243) rejects the notion that the gandharva's claims to the bride were originally thought of in negative terms. The bride, like the soma (see below), was under the guardianship of the gandharva while in a sort of "quarantine", required to divest her of potentially dangerous influences. Afterwards, the gandharva was simply asked to leave, without any threat or force being necessary. This is the picture gained from RV 10.85, where Viśvāvasu is said to have possessed the bride after Soma but before Agni, and is later implored to leave her to her husband and seek out another, unmarried girl. The later conception "may have had its origin in feelings of 
these texts, where, as we shall see, the gandharvas often appear as possessing women. In this particular context, however, it can also be seen as a negative side of their power over procreation; ${ }^{65}$ note that the gandharvas and apsarases, according to the PB passage quoted earlier, preside over a person's "offspring and childlessness".

Almost all the texts discussed so far belong to post-rgvedic times. An outline of the historical development of this mythological being will, of course, not be complete without taking into account the references in the earliest Veda, however sparse, scattered, and obscure these may be. It should be made clear already here that the conception of the gandharvas in the RV seems to differ in some respects from that presented in the AV and Middle Vedic texts. This is, no doubt, partly due to changes or developments in the later conception - this, I suspect, is particularly true as regards the gandharvas' role in rituals but at the same time, the nature and style of the rgvedic hymns may account for some of the differences; and as the references to the gandharva in this Veda are sparse, too much should perhaps not be made of its silence concerning some typical traits of the gandharva (many of which do appear already in the AV).

\section{gandharvá- in the Rgveda}

We have neither the space, nor the need, to give an exhaustive survey of the earliest evidence, as this has already been studied in detail several times. ${ }^{66}$ The most prominent traits may be summarized as

frustration (not to say Freudian castration) on the part of the husband" (ibid.) while
his bride was in the care of someone else. Kuiper is probably right as far as the
"quarantine" is concerned, though the three-day period is, as we have seen, a younger
custom. I do not, however, think that the dismissal of the gandharva must "originally"
have been so unproblematic as Kuiper claims; the gandharva's desire for women is
already a prominent motif throughout the AV, the oldest parts of which cannot be
much later than RV 10.85, and though the lasciviousness of this kind of being is only
hinted at in the RV (e.g. 10.123 .5 , quoted below), this is so prominent a characteristic
of the gandharvas from the AV onwards that it is hard to see how it could have been
derived simply from a reinterpretation of the marriage custom (as Kuiper suggests),
rather than vice versa.
${ }^{65}$ Thus Oberlies 2009 .
${ }^{66}$ A handy summary is given by Macdonell 1897 , pp. 136-38. More in-depth studies
include Oldenberg 1894, pp. 244-50; Hillebrandt 1999, pp. 248-57; Wijesekera 
follows: the gandharvá- (almost always sing.) of the Rgveda is a celestial creature, with a somewhat unclear relationship to the gods, often appearing in the company of his lovers, the apsarases; his abode is in the waters (ap-), which are often specified as the heavenly waters - there is thus no discrepancy between passages locating the gandharva in the heavens (e.g. 9.85.12 and 10.123.7: "the gandharva stood upright upon the firmament" ${ }^{\prime 67}$ ) and those that simply speak of "the gandharva of/in the waters". Some later texts have the gandharvas and apsarases residing in trees (AV 4.37.4; 14.2.9; TS 3.4.8.4 $4^{68}$ ), like the yakșas of post-Vedic religion, or (as for the apsarases) in rivers (AV 4.37.3; JB 1.42, $44^{69}$ ); and this might reflect more popular beliefs. The antiquity of the "gandharva of/in the waters" $(9.86 .36 ; 10.10 .4)$ is, however, clear from parallels in ancient Iranian texts; here we find (Yašt $5.38 ; 15.28 ; 19.41)$ the gandarəßa- as a monster inhabiting the celestial sea Vourukaša, where it is eventually slain by the hero Kərəsāspa. Traces of some similar myth have been seen in RV 8.1.11 and 8.77.5, where Indra is said to have defeated and "pierced" (abhi ... atrnad) the gandharva under unclear circumstances. This is in striking contrast to the hymn 10.139 , where the gandharva appears as Indra's helper, aiding him (according to Lüders' interpretation ${ }^{70}$ ) in his search for the sun that was lost in the waters. The apparently demoniacal nature of the gandharva in book 8 being in contrast to his rather lofty appearance elsewhere in the RV, Iranian influence can perhaps not be entirely ruled out. ${ }^{71}$ The Iranian

1994a; Oberlies 2005; Barnett 1928. Haas (2004) gives all the RV occurrences of the word, with Sāyana's commentary and a German translation; though one may not always agree with the author's conclusions.

${ }^{67} \bar{u}$ rdhvó gandharvó ádhi nắke asthād. Cf. AV 14.2.36, where it is said of Viśvāvasu, when he has been driven away from the bride: "This god has gone to the highest dwelling." (ágant sá deváh paramám sadhástham.)

${ }^{68}$ Cf. Samyutta Nikāya 3.250, where the gandhabbas are said to inhabit the fragrant parts of trees; and DN 3.203-4, where they are grouped together with yakkhas and other, terrestrial, demons that haunt travelling or meditating monks and nuns (presumably in the wilderness).

${ }^{69}$ Cf. already RV 5.41 .19 (Urvaśī and the rivers). In the story of Urvaśi and Purūravas, the apsarases are swimming in a lotus-pond in the shapes of aquatic birds (āti-; ŚB 11.5.1.7; cf. RV 10.95.9).

${ }^{70}$ Lüders 1959, pp. 537-41.

${ }^{71}$ Oberlies (ibid., p. 100) notes in this regard that the eighth book of the RV, in which both passages are found, has been considered as having a more westerly origin than other books; cf. also Hillebrandt 1999, p. 252. Significantly, RV's book 8 was 
evidence does, however, confirm that there was originally only one gandharva; the plural of the word being, with a single exception, ${ }^{72}$ found only in the younger parts of the RV, and only twice. ${ }^{73}$

Though it is of slight relevance to the present study, it may be noted that the word gandharva- - and thus, it seems, the being designated by it - is usually considered a substrate word in IndoIranian. ${ }^{74}$ This assumption would be supported by the fact that the word is not found in any of the "family books" of the RV (with the single exception of 3.38.6), thus pointing, as Hillebrandt noted, ${ }^{75}$ to a late acceptance of this kind of being into the brahmanical religion. While Indian tradition, from the earliest times, has derived the word from gandha- "fragrance", ${ }^{76}$ and the beings are said to subsist on the mere fragrance of plants and herbs, ${ }^{77}$ this has commonly been rejected as a pseudo-etymology; indeed, "fragrance" does not occupy a prominent place in the lore around the gandharvas, and the notion of their feeding on fragrance (as well as the part played by scents in their

composed by the Kānvas and Āngirasas, who are also (as is now generally recognized; cf. Parpola 2015, pp. 131-33) the poets behind the Atharvaveda, where the gandharva's demoniac nature reminds one of RV 8.1.11 and 8.77.5. A reminiscence of a connection with the atharvavedic seers may be seen in the BĀU 3.3.1 and 3.7.1, where two gandharvas who have possessed women identify themselves as "Sudhanvan Āngirasa" and "Kabandha Ātharvana", respectively.

${ }^{72} \mathrm{RV}$ 3.38.6c-d, in which the poet addresses some unnamed gods with the words, "Having come here with my mind, I saw even the wind-haired Gandharvas under your commandment" (transl. Brereton and Jamison; ápaśyam átra mánasā jaganvấn vraté gandharvắă ápi vāyúkeśān).

${ }_{73}^{7 n}$ In 9.113 .3 and 10.136.6. Cf. Hillebrandt 1999, pp. 252-53.

${ }^{74}$ Thus Kuiper (1996, pp. 225-26): "Since an interchange $v / b$ is excluded in words of IE origin, the different names [gandharva- and gandərəßa-] point to a foreign (that is, non-Indo-European) origin ... The interchange of a phoneme $/ r /$ with $a r$ in IndoAryan cannot represent an IE ablaut, nor is / $r /$ likely to have occurred in a non-IndoEuropean language. The name that was adopted into Proto-Indo-Iranian may have been ${ }^{*} G(h) a n d h(a) r b a-/ * G(h) a n d h(a) r w a$ - or, if Skt $d h$ is due to popular etymology, *gand(a)rb/wa-." Witzel (2003, pp. 39, 55) considers the word as part of a Central Asian linguistic substrate in Indo-Iranian, comparing it with other terms having the "suffix" *-arwa-, "which is seen only in religious terms"; cf. Vedic atharvan-, Śarva-. Cf. also Witzel 2004, esp. p. 605 n. 41, pp. 615, 620ff.

${ }^{75}$ Hillebrandt 1999, p. 252.

${ }^{76}$ Probably already in RV 10.123 .7 , where the heavenly gandharva clothes himself in a scented (surabhi-) garment.

${ }^{77}$ Thus AV 8.10.27, 12.1.23; cf. ŚB 9.4.1.4, JUB 3.25.4. The Buddhist Samyutta Nikāya, 3.250, has the gandhabbas inhabiting "fragrant" roots, leaves, and other parts of trees. 
ritual, as seen above) is perhaps more likely to have been derived from the "etymology" ${ }^{78}$ Of doubtful derivation is also the word apsaras, denoting the female partners of the gandharvas. The meaning "moving $\left(s r^{-}\right)$in the waters $(a p-) ",{ }^{79}$ though in keeping with their nature as nymphs dwelling in rivers and other bodies of water, is now usually rejected in favor of the reading a-psaras, "shameless", apparently referring to their promiscuous character. Whether they were "originally" the spouses of the gandharvas (as they are already in RV), or have been paired with them later due to their similar characteristics, is a question of no greater bearing to this study; while the late passage 10.10.4 (cf. 10.11.2) speaks of "the gandharva in the waters and the water-maiden" (gandharvó apsv ápyā ca yóṣa) without explicitly calling the "water-maiden" an apsaras (she is referred to as gandharvitin 10.11.2), it seems precocious to infer that the gandharvit- was the "original" spouse of the single gandharva. ${ }^{81}$ In my view, the characteristics shared by gandharvas and apsarases already in the RV - among which are, as we shall see, beauty, eroticism, dwelling in water - are too prominent to permit the conclusion that these groups of beings are of separate origins. Kuiper ${ }^{82}$ saw the "gandharva of the waters and the water-maiden" of 10.10 .4 as the original conception of the single gandharva, living with his wife in the primordial waters, and believed that this conception survived in the legend (to be discussed later) told in JB 1.125-27, where we meet with a gandharva and his spouse - what kind of being she is we are not told - in their home floating on the waters. While not contesting that there was originally only one gandharva, I am not fully convinced by these isolated passages - one occurring in the very latest stratum of the RV, the other in one of the younger Brāhmaṇas. In the AV and some later texts, we find a single gandharva in a polygamous or even

\footnotetext{
${ }^{78}$ Cf. however Mayrhofer, s.v., who considers the possibility of a derivation from *gandhas-/*gandhar-.

${ }^{79}$ This is the etymology given in the Nirukta (5.13); the same understanding of the word seems to underlie AV 2.2.3c-d, where the apsarases are described as moving to and fro in the ocean (samudrá āsām sádanam ma āhur yátah sadyá á ca párā ca yánti).

${ }^{80}$ Cf. e.g. Mayrhofer, s.v. (who also considers the meaning "shapeless").

${ }^{81}$ Cf. e.g. Joshi 1977, p. 32.

${ }^{82}$ Kuiper 1996.
} 
promiscuous relationship with several apsarases; ${ }^{83}$ in RV 10.123.5, quoted below, we do indeed find the heavenly gandharva accompanied by a single apsaras, but he is here described as her "lover" (jārá-), perhaps suggesting something like the promiscuous relationships of these beings as known from later texts.

This is perhaps the only rgvedic passage where the erotic associations of the gandharva, well known from the AV onwards, appear clearly. Otherwise, there are notable differences in the conceptions of the lofty, celestial gandharva of the RV and of the semi-demoniac being of later texts. Its incubus nature is implied only in the late wedding hymn 10.85 , which is also one of the few rgvedic references to its potentially harmful or menacing nature. Conceivably, the two references in book 8 to a gandharva-demon defeated by Indra may point to a conception of this being more in keeping with that found in the AV and later texts. The tendency of the rgvedic singers to elevate deities and spirits by associating them with celestial gods like Soma or the Sun, might be responsible for the very different conception of the gandharva which appears in several hymns. Passages like 3.38.6 (the only mention of the gandharvas in one of the family books), where we encounter the "wind-haired gandharvas" under the command of some unnamed gods, and 10.136.6, describing the journey of a flying shaman along "the course of the apsarases and gandharvas and the wild beasts" (apsarásām gandharvấnām mrgáṇạm cárane), seem to imply a parallel, perhaps more popular, conception of these beings as terrestrial or atmospheric spirits. However, the rgvedic references to the gandharva(s) are scanty and often cryptic, and probably do not allow us to paint a complete picture of the earliest conception of these beings.

A few passages have been interpreted as implying a connection between the gandharva and the womb, or birth. These induced Pischel to consider the gandharva as identical with the fetus, and have more recently been treated by Haas (2004) in comparison with the Buddhist material. ${ }^{84}$ Unfortunately, most of the relevant verses appear in

${ }^{83}$ AV 2.2.3-5, 14.2.35; TS 3.4.7; VS 18.38-43; PB 12.11.10. Possibly already in RV 9.78.3 (Soma in the waters surrounded by apsarases).

${ }^{84}$ This latter publication consists of a translation and study of all the RV passages mentioning the gandharva(s), in the light of Sāyana's medieval commentary; this choice of method is of course open to criticism, and the author devotes some space to defend it. Hardly any attention is given to AV or to Middle or Late Vedic texts. The 
(intentionally) obscure hymns of riddle-like poetry, and their exact import is far from clear. It should also be noted that words like garbhá- ("womb" or "fetus") and yóni- ("womb") occur frequently in this kind of hymns, usually in a mystical sense as referring to the divine "births" of Agni, Soma, or the sun.

RV 10.123.5 refers to the gandharva and apsaras in a kind of love-play:

The apsaras, the young woman, smiling towards her lover, bears him in the highest heaven. Moving inside the dear one's womb, being dear, this Vena sat down on the golden wing. ${ }^{85}$

The "lover" of the apsaras is the gandharva, being mentioned in the immediately preceding $10.123 .4 \mathrm{~d}$ ("the gandharva knew the immortal names" ${ }^{\text {" }}$ ) and again in v. 7 ("The gandharva stood upright upon the firmament, wielding his bright weapons, turned hitherwards" ${ }^{87}$ ). The notion that he moves inside her womb may refer either to sexual activity or to pregnancy; the latter interpretation seems to be supported by the word bibharti "bears"; the verbal root bhar- being often used to denote pregnancy or birth-giving. Possibly, the reference

ultimate purpose of the work is to demonstrate that the gandharva of the RV is an atmospheric "Zwischenzustand"-creature, mediating between heaven and earth, and thus an immediate precursor of the much later concept of the gandhabba, as (in the interpretation embraced by the author) a deceased spirit waiting to be reborn. Haas further attempts to read seeds of the later transmigration doctrine into the passages concerned. While any study of the elusive rgvedic gandharva should be welcome, there are obvious problems with the author's choice of method (cf. the wholly negative review by Jamison [2008]), in adducing late Buddhist texts and medieval exegesis to illuminate the RV passages, while passing over the later Vedic literature. The mediating character of the gandharva is, as we shall see, probable enough, but the passages studied by Haas are often enigmatic enough for an interpretation placing the gandharva in any kind of "middle" position to be, more or less forcefully, applied. (Cf. Jamison, p. 395: "[Haas'] other means of handling the problem is to see all sorts of "in-between" positions and states in the Rigvedic Gandharva passages, and then to argue that any kind of "zwischen" is equivalent to the Zwischenzustand between death and rebirth. Thus, sunrise, the production of words from thoughts, the freeing of the Vala cows, the Gandharva's role as intermediate bridegroom in the wedding hymn, and name-giving can all be used as evidence for the Rigvedic origins of the later, specifically Buddhist, function of the gandharva.")

${ }^{85}$ apsará jārám upasiṣmiyāṇá yósā bibharti paramé vyòman/ cárat priyásya yóniṣu priyáh sán sî́dat pakṣé hiranyáye sá venáh//.

${ }_{86}$ vidád gandharvó amŕtāni náma.

${ }^{87} \bar{u}$ rdhvó gandharvó ádhi náke asthāt pratyán citrá bíbhrad asyáayudhāni. 
to the gandharva moving in his lover's womb may have an intentional double meaning, in which case the verse would give expression to a kind of mysticism with the gandharva being both the lover and the child of the apsaras. In any case, it does refer to the lustful nature of the gandharva(s), which elsewhere seems implied only in 10.85 .

Another difficult passage is RV 9.83.4. The immediately preceding half-verse $(9.83 .3 \mathrm{c}-\mathrm{d})$ runs as follows: "The magicians have measured it out through magic; the fathers, watching over mankind, have placed the germ (gárbha-)." ${ }^{88}$ Then follows verse 4: "The gandharva guards its place here; the awesome one protects the generations of gods. With his noose the noose-lord seizes the foe; the supreme well-doers have consumed the honey." 89 The hymn is, like all others in RV,s book 9, dedicated to Soma, and the "honey" is, as usual, the soma-drink, apparently consumed by the pious dead in heaven. As Kuiper and Oberlies have shown, and as we will discuss later on, the rgvedic gandharva is the guardian of the soma in heaven; and it is obviously in this function he appears in this verse. But the preceding, somewhat less clear, verse may indicate yet another function; here, the soma is, as often, likened to a germ or fetus (gárbha-). May the immediately following mention of the gandharva indicate a role as protector of the fetus or embryo in the womb? The mention of the gandharva's protecting the generations or births (janiman-) of the gods would perhaps support such an interpretation, though its meaning is not very clear. If the proposed interpretation is correct, however, the gandharva's association with the fetus, as well as its guardianship of the soma, may both be expressed in these verses through the poetical designation of soma as a "fetus".

A connection with the womb is again met with in RV 10.177.2. I quote here the first two verses of this short (three verses) but obscure poem:

The bird, anointed with the magic of the asura, the discerning ones behold with their heart, with their mind. Inside the ocean the seers discern [it]; the masters long for the place of the sun-rays.

\footnotetext{
${ }^{88}$ māyāvíno mamire asya māyáyā nrcákșasah pitáro gárbham á dadhuḥ/l.

${ }^{89}$ gandharvá itthá padám asya rakșati páti devánām jánimāny ádbhutah/ grbhṇáti ripúm nidháyā nidhápatih sukŕttamā mádhuno bhakṣám āśatal/.
} 
The bird carries Speech in its mind; the gandharva proclaimed it inside the womb. That flashing, sun-like inspiration the seers guard in the place of Truth. ${ }^{90}$

"The bird" is presumably the sun (thus Sāyana) in the ocean of heaven; here appearing in a mystical sense as connected with esoteric insight (Geldner: "das innere Licht der seherischen Erkenntnis und Erleuchtung im Herzen"). The gandharva is mentioned as having proclaimed (sacred) Speech to it, "inside the womb". Whatever the symbolic import of all this, the gandharva here, again, appears to be connected with the womb.

Some similar conception may be the basis of a passage in the oft-discussed dialogue-hymn 10.10. In an attempt to make her twinbrother, Yama, agree to an incestuous relationship, Yamī appeals to divine will, stating that the gods have preordained this incestuous union. In v. 4, Yama counters her arguments; the second half-verse runs thusly: "The gandharva in the waters and the water-maiden that's our origin [lit. "navel'], that's our ultimate kinship-bond." meaning of these words has been the subject of much discussion. The mention of the "kinship-bond" (jämi-) and the nābhi-, meaning "navel" but often used in the sense of origin or connection through birth (Jamison and Brereton: "umbilical tie"), has led a number of scholars to the conclusion that the gandharva and the "water-maiden" - clearly an apsaras ${ }^{92}$ - are the parents of Yama and Yamī. Such a conclusion, however, has some difficult implications, as Yama's (and therefore, presumably, Yamī's) parents are elsewhere (RV 10.17.1ff, etc.) said to be the semi-divine Vivasvant and Saranyū, daughter of the god Tvaștr; the patronymic Vaivasvata is used of Yama even in post-Vedic tradition. The evidence being unanimous on this point, the question is what to do with the gandharva and the water-maiden of RV 10.10.4. Some scholars have tried to solve it all by simply identifying the gandharva as Vivasvant. ${ }^{93}$ However, Vivasvant is

${ }^{90}$ patamgám aktám ásurasya māyáyā hrdà paśyanti mánasā vipaścitah/ samudré antáh kaváyo ví cakșate márīcīnām padám ichanti vedhásahl/ patamgó vắcam mánasā bibharti tầm gandharvò 'vadad gárbhe antáh/ tạ́m dyótamānām svaryàm manị̂áam rótásya padé kaváyo ní pānti//. (10.177.1-2.)

${ }^{91}$ gandharvó apsv ápyā ca yósā sá no nábhih paramám jāmí tán nau.

${ }^{92}$ Cf. the ápyā ... yóșanā of the following hymn (10.11.2), who is called a gandharvít-.

${ }^{93}$ E.g. Barnett 1928; Wijesekera 1994a, p. 187; Haas 2004, p. 137 (following Sāyana who, indeed, makes this identification). 
nowhere else referred to as a gandharva, or even put in connection with these beings; nor is Saranyū ever called an apsaras, or a "watermaiden". Unless we assume an alternative, otherwise unattested, tradition, according to which Yama and his sister were begotten by a gandharva and an apsaras, we must therefore conclude that the verse in question does not refer to their parentage.

Of what kind, then, is their relationship to these beings? Schneider, after refuting the parenthood-theory, proposes, with some caution, "bei Gandharva und die Wasserfrau an eine weiter zurückliegende Abkunft zu denken, etwa an das Urpaar eines clans der Amrtas [immortals; gods], für den das Gebot der Exogamie ... gilt, das ja, religionssoziologisch betrachtet, nicht vom Verbot des Inzests zu trennen ist" ${ }^{\text {"4 }}$. Yama's argument against the proposals of incest would, then, refer back to the "immortals", mentioned by Yamī in the preceding verse (v. 3) as wishing for the intercourse to take place. According to Schneider's interpretation, Yama would thus counter his sister's argument by referring to the will of even higher immortals. This explanation of the passage differs from some others in actually considering what relevance Yama's invoking of the (will of the) gandharva and the maiden may have for his argumentation: these beings are, clearly, of another kind than the "immortals" invoked by Yamī, and constitute the "ultimate" kin of the twins. The same kind of interpretation has been proposed by Kuiper, ${ }^{95}$ who takes paramá- to

\footnotetext{
${ }^{94}$ Schneider 1967, p. 15.

${ }^{95}$ Kuiper 1996, p. 252 . He rejects the possibility that the conception of gandharvas as deities presiding over offspring might explain the passage under discussion, claiming that, "Yama's appeal to the Gandharva as his ultimate origin, while declining Yamī's proposal, is even a strong argument against the Gandharva's being a genius of procreation"; the latter notion is, according to Kuiper, not to be found in the oldest Vedic texts. He does not, however, discuss those RV passages which, however obscure, connect the gandharva with the womb or the embryo. In support of his belief that the gandharva and his consort constitute a primordial couple, more ancient than the gods, Kuiper depends exclusively on the much later JB 1.125-27 and 1.154-55 (to be discussed later); yet even these passages do not state that these beings are older than the gods, but only that they did not take part in the war between gods and asuras. - Oberlies $(2009 ; 2012$, p. 144) sees the gandharva and the apsaras of RV 10.10 .4 as presiding over procreation, but also seems to connect this function with their being primordial begetters: "the gandharva and the apsaras who dwell in the heavenly waters and near the sun beget the first human beings, who are believed to descend from the sun" (2009). Assuming that the sun here, as the begetter of mankind, is
} 
mean that the gandharva and his consort are the primordial ancestors of Yama and Yamī, as well as the gods.

This is certainly possible. But the idea of a gandharva and an apsaras constituting some sort of "Urpaar" or being older than the gods does not, to my knowledge, find any support either in the RV or in younger texts. Rather, the true nature of the gandharva and the water-maiden may be explained in the light of the first half of the next verse (v. 5 a-b), in which Yamī counters her brother's argument: "In the womb, the Begetter made us husband and wife - god Tvaștr, the Impeller, possessor of all forms. " artisan of the gods, who among other things is credited with shaping the embryo in the womb (cf., for instance, RV 10.184.1); this activity of his usually being referred to as the shaping of "forms" (rupa-) thus his epithet Viśvarūpa-, "(possessor of) all forms". ${ }^{97}$ The argument, which is as clear as it gets, is that the shaper of embryos intended the incest of the twins to take place already when shaping them inside the womb. It seems likely that the gandharva and the water-maiden stand for some similar, but not identical, activity; for instance, the placing of the embryo inside the womb. Yama's argument against incestuous intercourse would, then, be something like this: while Yamī invokes the will of the immortals - among which the twins, as Schneider points out, belong - her brother counters this argument by pointing beyond their own generation, or that of their parents; declaring the gandharva and the water-maiden to be their ultimate (paramá-) kin and origin, having brought them as embryos to the womb, perhaps from some supra-terrestrial sphere like the heavenly waters. This may not necessarily mean that these two beings are opposed to incest, but rather nullifies the authority through kinship - of the immortals. (Possibly, however, there is an implicit reference to the sexual habits of the gandharvas and apsarases, which are clearly not incestuous but rather, as we shall see, promiscuous.) Yamī, in her turn, counters this argument by invoking the will of the god Tvaștr, whose part in their creation was similar to that of the gandharva and the water-maiden - he shaped them as embryos in the womb and, presumably, decided their destinies. This

Vivasvant (cf. Oberlies 2012, pp. 218-19, 321), i.e., Yama's and Yamī's father, I am not sure who begets whom according to this reconstruction.

${ }_{96}$ gárbhe nú nau janitá dámpatī kar devás tváștā savitá viśvárūpaḥ/.

${ }^{97}$ See in general Macdonell 1897, pp. 116-18. 
interpretation is, however, by no means certain. Wholly implausible is, in any case, Pischel's attempt to identify the gandharva here with the fetus. ${ }^{98}$

\section{Gandharvas, soma, women, and the notion of exchange between the worlds}

One important trait of the rgvedic gandharva is its connection with sóma- ${ }^{99}$ As Lüders ${ }^{100}$ demonstrated, this sacred herb was thought to have its origin in the waters of heaven, i.e., in the abode of the gandharva; and indeed, we find the gandharva as guardian of the soma in the heavenly waters: here is the "firm place of the gandharva" (gandharvásya dhruvé padé, 1.22.14), dripping with ghee and milk (i.e., probably soma); "here the gandharva guards his place" (gandharvá itthá padám asya rakșati, 9.83.4), where the well-doers drink the "honey" (mádhu-; soma); ${ }^{101}$ here is the "flood" (sindhu-) in the "highest heaven" (paramé vyòman), where "they lick the streams of ambrosial honey" (rihánti mádhvo amŕtasya vấnīh) and the gandharva stands "upon the firmament" (ádhi nắke) (10.123.3-5, 7). In 9.113.3, the gandharvas ( $\mathrm{pl}$.) are mentioned as placing the juice (rása-) in the soma (plants), ${ }^{102}$ apparently having brought it from the celestial waters. Oberlies has postulated an Indo-Iranian proto-myth in which the gandharva, dwelling in the waters of heaven, was defeated by a god or hero in a struggle for the divine beverage (i.e., * sáuma-)

\footnotetext{
${ }^{98}$ Pischel \& Geldner, pp. 78-9.

${ }^{99}$ See especially Kuiper 1996; Oberlies 2005; Hillebrandt 1999, pp. 248ff; cf. also Barnett 1928.

${ }^{100}$ Lüders 1951-59.

${ }^{101}$ For the gandharva as guardian of soma, see further Oberlies 2005. I do not think, however - like Oberlies and others before him - that Soma is "identified" with the gandharva in some passages. As Hillebrandt pointed out (1999, p. 249), gandharva- is several times used in the RV as an appellative for various other entities. When Soma in 9.78.3 is described as surrounded by the "apsarases of the ocean" (samudriy $\bar{a}$ apsaráso), it is a matter of mere comparison: the soma-stalk soaked in water is (by implication) likened to the gandharva amidst the apsarases in the heavenly waters (cf. AV 2.2). If 9.85 .12 and 86.36 actually do identify Soma and the "heavenly gandharva", then these are isolated instances, and the identification an expression of typical priestly speculation.

${ }^{102}$ parjányavrddham mahișám tám sứryasya duhitábharat/ tám gandharváh práty agrbhṇan tám sóme rásam ádadhur índrāyendo pári srava //.
} 
guarded by it. ${ }^{103}$ This may be possible, but it should be noted that, while the haoma- is indeed situated in the lake Vourukaša, it has no part in the gandarəßa-myth; nor does soma, in those passages which mention the gandharva's defeat at the hands of Indra. Moreover, the gandharva is, as Oberlies himself notes and as Kuiper was the first to emphasize, elsewhere in the RV clearly guarding the soma for the benefit of the gods. In fact, as late as in the Kaușitaki Brāhmaṇa (12.4.2) we find the notion that "the Gandharvas as commissioners in the waters guard the Soma of Indra" ${ }^{, 104}$ (transl. Keith). ${ }^{105}$ This raises some questions as to the exact relationship between the gandharva(s) and the gods. In Middle Vedic texts we do find a myth - the most common one which involves the gandharvas - in which the soma is wrested from the gandharvas by the gods by means of trickery. This myth appears in several texts, but its plot is basically the same, except for a few variants: ${ }^{106}$ the gandharvas barter the soma in exchange for the goddess Speech $(V \bar{a} c)$, the personification of Vedic sacred utterances. It usually begins with the gods obtaining the soma from heaven, only to have it stolen from them by the gandharva Viśvāvasu. ${ }^{107}$ This might seem strange if the view is accepted that the gandharvas originally guarded the soma for the gods; conceivably, the nature of these beings as intermediaries (for which see below), holding the soma between its descent from the highest heaven and before its reaching the gods or humans, has played a part in the formation of the younger myth. Possibly the mention of the gandharvas as "seizing" (grbh-) the heaven-born soma in RV 9.113.3 may have contributed too.

I quote here the version of the myth found in the Satapatha Brāhmana. After the theft of the soma, the gods ponder on how to retrieve it:

\footnotetext{
${ }^{103}$ Oberlies 2005, pp. 99f.

${ }^{104}$ gandharvā ha vā indrasya somam apsu pratyāhitā gopāyanti.

105 Also in MS 3.8.10, where some gandharvas are designated the "soma-guardians of the gods" (devānăm somarákṣaya); cf. Kāṭhaka Saṃhitā 24.6, TS 1.2.7h; Kuiper 1996, p. 252.

${ }^{106}$ MS 3.7.3; Kāṭhaka Saṃhitā 24.1; Kapișṭhala-Kațha Saṃhitā 37.2; TS 6.1.6.5-6; $\mathrm{AiB}$ 1.27; ŚB 3.2.4.1-7. Cf. quotations in Lévi 1898, p. 33. Ludvik (1998) makes a comparison of all the versions, including the one from the recently edited Vādhūla text.

${ }^{107}$ In the soma ritual, concern are sometimes expressed that the gandharvas may steal or attack the soma: TS 1.2.9a, ŚB 3.6.2.19-20.
} 
They said, 'The Gandharvas are fond of women: let us send Vāc (speech) to them, and she will return to us together with Soma.' They sent Vāc to them, and she returned to them together with Soma. The Gandharvas came after her and said, 'Soma (shall be) yours, and Vāc ours!' 'So be it!' said the gods; 'but if she would rather come hither, do not ye carry her off by force: let us woo her!' They accordingly wooed her. The Gandharvas recited the Vedas to her, saying, 'See how we know it, see how we know it!' The gods then created the lute and sat playing and singing, saying, 'Thus we will sing to thee, thus we will amuse thee!' She turned to the gods; but, in truth, she turned to them vainly, since she turned away from those, engaged in praising and praying, to dance and song. Wherefore even to this day women are given to vain things: for it was on this wise that Vāc turned thereto, and other women do as she did. And hence it is to him who dances and sings that they most readily take a fancy. ${ }^{108}$ (Transl. Eggeling; transliteration modernized.)

There is an intended irony in this story which seems to have passed unnoticed in most discussions: ${ }^{109}$ the usual roles of the gandharvas and

\footnotetext{
${ }^{108}$ ŚB (Mādhyandina) 3.2.4.3-6: te hocuh, yoșitkāmā vai gandharvā vācam evaibhyah prahinavāma sā nah saha. somenāgamișatīti tebhyo vācam prāhinvant sainānt saha somenāgachat. te gandharvā anvāgatyābruvan, somo yușmākam vāg evāsmākam iti tatheti devā abruvann iho ced āgān mainām abhịsaheva naișta vihvayāmahā iti tām vyahvayanta. tasyai gandharvāh vedān eva procira iti vai vayam vidmeti vayam vidmeti. atha devāh vīnām eva srșțā vādayanto nigāyanto niṣedur iti vai vayam gāsyāma iti tvā pramodayisyāmaha iti sā devān upāvavarta sā vai sā tan mogham upāvavarta yā stuvadbhyah śamsadbhyo nrttam gìtam upāvavarta tasmād apy etarhi moghasamhitā eva yoșā evam hi vāg upāvartata tām u hy anyā anu yoṣās tasmād ya eva nrtyati yo gāyati tasminn evaitā nimiślatamā iva.

${ }^{109}$ Ludvik (1998, pp. 348-49 n. 10), in discussing this myth, brings up the fact that "song is the domain of the gandharvas", but then concludes, "By the time of the Mahābhärata, the gandharvas are indeed musicians (see Hopkins 1915: 154), but this does not seem to have been the case in Vedic texts. At most, the AV (4.37.7ab) mentions the 'dancing' gandharva: anrítyatah... gandharvásya..." While this may be true, gandharvas do appear as celestial singers fairly early; the gandharva Pañcasikha of the Buddhist Nikāyas is both a singer and a player of the vinna or lute (like the epic Nārada), and gandharvas carrying this instrument appear on the reliefs of Bharhut, Sikri, and Loriyan $\left(3^{\text {rd }}\right.$ to $1^{\text {st }}$ cent. BC.; cf. Hillebrandt 1987, p.184). This widespread conception, found in the brahmanical as well as Buddhist traditions, must be more ancient than the early Buddhist texts. The Vedic notion of the gandharvas and apsarases as constantly frolicking and feasting, furthermore, should probably not be separated from the conception of them as singers and dancers; note also that the apsarases are depicted in JB as indulging in "dance and song and the sound of the vīṇā" (nrttagitam vinnăghoṣo, JB 1.42, 44), and their abode is in AV 4.37 .5 said to be resounding with cymbals and lutes. On the other hand, I am not sure if the vịnā in the
} 
the gods, respectively, are temporarily switched. It is, usually, the gandharvas who are occupied with dancing, singing and music; in post-Vedic mythology (Buddhist; epics, etc.) we find them typically as musicians of heaven (cf. gāndharvaveda-, the art of music), and their wives, the apsarases, as celestial dancers. ${ }^{110}$ But already in the Atharvaveda (4.37.7) there appears a menacing, "hither-dancing, crested" (anrityatah ... śikhandino) gandharva, and the gandharvas and apsarases in general are said to "revel in feasting" (sadhamádam mad; 7.109.3,5; 14.2.34; cf. 4.34.3; 4.38.3 [dancing apsarases]). This is a constant feature in later literature, which associates them with frolicking, games, and coquetry; the "swings" referred to in AV 4.37 recur in PB 12.11.10, where the gandharva Ürnāyu is introduced while "swinging amidst the apsarases" (apsarasām madhye prénkhayamānam), and in JUB 3.25 the gandharvas are connected with the attributes fragrance (gandha-), joy (moda-), and pleasure (pramoda-), and the apsarases with laughter (hasa-), play (krīida), and sexual intercourse (mithuna-). This corresponds well to the nature of these beings as depicted in the epics and early Buddhist texts. ${ }^{11}$

Believing, thus, that the goddess of sacred speech will not be enticed by such fleeting pleasures as dance and song, the gandharvas in the myth revert to reciting the Veda, laying off their old style; but the gods, understanding the mind of women, start imitating the gandharvas' old habits, and win over the goddess.

myth is to be connected with that belonging to the goddess Sarasvatī (often identified with Vāe) in post-Vedic mythology (Ludvik, p. 357).

${ }^{110}$ Hillebrandt 1987 (1906), pp. 183-84; Wijesekera 1994a, pp. 192-93; Hopkins 1915, pp. 154ff. Although the singing and vīnā-playing gandharva Pañcasikha of early Buddhist tradition (Dīgha Nikāya, etc.) is not (to my knowledge) found in Brahmanical texts, it is certainly interesting that an apsaras named Pañcacūdū, "FivePlaits" (the same meaning as pañca-śikha-) appears in the Mbh (Poona edition: 12.319.18; 13.3.11, 38.2ff, 151.10), and apparently already in TS 5.3.7.2, which prescribes the laying down (on the fire altar) of a pañcacoda $\bar{a}$ brick for winning the company of apsarases in the next world. Cf. also ŚB 8.6.1.11ff (the pañcacüda bricks and apsarases). The epithet sikhandin- of the gandharva in AV 4.37.7 indicates a similar hairstyle. The Sikhandin of Dīgha Nikāya 2.263, son of Sakka's charioteer Mātali, is apparently a gandhabba; he married Suriyavaccasā, daughter of the gandhabba Timbarū (Tumburu of Sanskrit texts), but later lost her to Pañcasikha. Elaborate hairdressing may reflect the usual concern of these beings with beauty and sensuality; cf. also Vasilkov 1990, pp. 394-95, for some different suggestions.

${ }^{111}$ Cf. Hopkins 1915, pp. 153ff; Bhattacharyya 2000, pp. 57-8, $123 \mathrm{ff}$. 
The ritualistic import of parts of the myth has long been recognized, and is indeed made explicit in the sources themselves. The cow used for (ritualistically) buying the soma-stalks is thus declared to be Vāc; and, before its preparation, the soma is left exposed for three days, during which it is said to be in the ward of the gandharvas. ${ }^{12}$ Kuiper pointed out the parallel between the latter practice and the three nights during which the bride was (apparently) in the care of Viśvāvasu, and provided the following interpretation: "The two parallel cases confirm the conclusion that the Vedic 'Tobiasnächte' involved a kind of quarantine, which was required in order to divest the bride and Soma of their inauspicious nature." This theory of a "quarantine" has been expanded on in a paper by Oberlies, ${ }^{114}$ who explains the main function of the Vedic gandharva as connected with transfer and mediation: besides guarding the soma in the heavenly waters, the gandharva is also responsible for transferring it to earth, as reflected in the ritual but also hinted at already in RV 9.113.3, where the gandharvas are said to have put the soma-juice (rasa-) in the plants (on earth):

The buffalo, caused to grow by Parjanya, that the daughter of the sun has born - that one the gandharvas received and placed as sap in the soma. Flow, O Soma, for Indra! $!^{15}$

The notion that the daughter of the sun "bore" (bhar-) the heavenly soma is interesting; this word often has the meaning "to be pregnant". There may, thus, be an intended analogy to the gandharvas' connection with embryos - the gandharvas place the sap in the soma plant, in the same way as the embryo in the womb.

The gandharvas in this passage appear in a sort of intermediary position; they possess the soma after the "daughter of the sun" (in heaven), but before its descent to earth. The case is similar with the bride: as for 10.85.40-41, where the bride is said to have belonged first to Soma, then to the gandharva, to the (nuptial) fire, and finally to the bridegroom. Oberlies points out that the gandharva here appears in a mediating position, possessing the bride before the marriage

\footnotetext{
${ }^{112}$ Cf. Kuiper 1996, pp. 234 ff.

${ }^{113}$ Kuiper 1996, p. 252.

${ }^{114}$ Oberlies 2005. More generally in Oberlies 2009; 2012, pp. 142-45.

115 parjányavrddham mahiṣám tám súuryasya duhitábharat/ tám gandharvàh práty agrbhṇan tám sóme rásam ădadhur indrāyendo pári sraval/.
} 
ceremonies, but after Soma (whatever his role here might be). He suggests that this is a recurring trait of the Vedic gandharva; the later notion of the bride being under the care of Viśvāvasu for three nights is thus explained with reference to the same idea: the bride, as a stranger coming from a different clan, must initially become divested of her "inauspicious nature" (Kuiper); the Gṛhyasūtras also prescribe rituals for neutralizing those of her "aspects" or "forms" (tanu-) which are harmful to the husband, as well as her evil eye (ghora- cakșus-). The soma, believed to originate in the other world, must similarly be put to three days' "quarantine" under the care of the gandharvas. To this are also compared the three days between initiation and the beginning of study required for the Veda-student, as well as the three days of inactivity following a funeral; the newly initiated student still being a stranger in his teacher's house, like the bride in the husband's, and the family of a deceased person having to go through a kind of "quarantine" to get rid of their impurity. ${ }^{116}$

This is an ingenious theory which would account for a great deal of the beliefs and practices surrounding the gandharvas. It has, however, aspects which are not unproblematic. The gandharva is nowhere in the source-texts mentioned in connection with the three days following the student's initiation, or the three days after a funeral. The three nights of chastity are, as Slaje has shown and as has been discussed above, a practice belonging to the latest strata of Vedic literature; and when it first appears, it is only in some texts put in connection with the gandharva. The staff in the bed is likewise a late element added to the practice; it is probable, if not certain, that the gandha-smeared cloth wrapped around it is an allusion to the gandharva. ${ }^{117}$ Oberlies accepts Slaje's outline of the development of the "Tobias-nights", adding that, though these may be a late feature, their precursor - the three nights following the end of the wife's period, after which cohabitation may take place - must "zu den dreitägigen 'Quarantänen' gehören". ${ }^{118}$ Even so, the precursor is not, either, associated with gandharvas. The only possible way to account for the three nights of chastity by means of Oberlies' theory would,

\footnotetext{
${ }^{116}$ Oberlies op.cit., p. 98.

${ }^{117}$ May this have been inspired by the gandharva's "clothing himself in a scented garment" in RV 10.123.7? But as mentioned in a previous note, the connection with both perfume and garments is common in Vedic and later literature.

${ }^{118}$ Ibid., p. 103 n. 28.
} 
then, be to explain them as a late development based on an ancient belief. This is probable enough; but it might also be that these nights are directly inspired by the "quarantine" of the soma. If that is the case, then there remains only one example of the three days' quarantine that can be directly connected with the gandharvas: that period during which the soma was believed to be under the care of these beings. This, in turn, could well be accounted for with reference to the gandharva's mythical function as guardian of the soma in heaven.

While the theory of the gandharva's intimate connection with the "quarantine"-period - however attractive - can be brought into question on some points, I do find convincing the characterization of gandharvas as beings responsible for various kinds of transfer. Similar suggestions have indeed been put forward, in less elaborated forms, by previous scholars. Barnett, for instance, suggested a parallel between the rgvedic gandharvas' placing the sap in the soma plants, and the later view making them responsible for successful procreation: "Both the waters and the Sōma are in the highest heaven [...] thence the waters, divine life-saps, are brought to earth by Gandharvas and Apsarases, who therewith impregnate men, animals, and vegetation. The Gandharva was thus constantly travelling from heaven to earth (rájasō vimánah, RV. X, CXXXiX. 5) for the benefit of the world ..." 119 Gonda, similarly, pointed to the gandharvas' function as mediators of sacred knowledge in the RV:

There can be hardly any doubt that "the gandharva" is represented as a mediator between the divine secrets and the minds of men: revealing speech and stimulating $d h \bar{\imath} h$ [inspired thoughts] he disclosed to them what they did not know previously ... The gist of the various statements of the character and activities of these deities is, in my opinion, that they are genii of conception and procreation, who keeping watch over the place of conception come as "lords of being" (AV. 2, 2, 1), dwelling in heaven, as "Wesenskeime" or "Seelenwesen", into touch with various divine beings and phenomena of a similar nature. As such they know and reveal the immortal (AV. 2, 1, 2) and the divine secret, found the immortal names (RV. 10, 123, 4,

${ }^{119}$ Barnett 1928, p. 706. 
cf. $10,139,6 ; 177,2)$, proclaim that highest abode that is in secret (AV. 2, 1, 2) and Vāc (Speech) in the womb. ${ }^{120}$

This association with hidden knowledge from the other world has also been pointed out by Kuiper, ${ }^{121}$ and, following him, by Oberlies; ${ }^{122}$ it is found in the RV and AV as well as in Middle Vedic literature. The gandharva found or proclaimed the "immortal names" (RV 10.123.4; 139.6); proclaimed (sacred) Speech in the womb (10.177.2); Viśvāvasu is asked to proclaim hidden things, "that which is reality and which we do not know" $\left(10.139 .5^{123}\right)$; the gandharva, "knower of the deathless" (amritasya vidvăn), should proclaim the supreme, hidden order (dhấma; AV [Śaunaka and Paippalāda] 2.1.2; RVKh 4.10.2). ${ }^{124}$ I believe this knowledge of divine things, as well as the association with soma, are to be explained as due to the gandharva's dwelling in the highest heaven. Its abode, the heavenly waters, in which soma is found (before its descent to earth), are, as Lüders has shown, the highest sphere of the Vedic cosmos; in their affinity we find the vault or firmament ( $n \bar{a} k a-)$, the "back" or ridge (sá̄nu-, prsțá-) of the universe. Here is "the heavenly gandharva of the waters, watching over mankind" (nrcákșasa-; 9.86.36), standing on or above (adhi) the firmament (RV 9.85.12; 10.123.5) and "watching all his forms (i.e., beings)" (víśvā rūpáa praticákșāṇo asya; 9.85.12b). ${ }^{125}$ The epithets indicate an omniscience of sorts; as to the latter one, we also find that "all forms" (víśva rūpó in early Vedic frequently denoting all beings, or the entire world) are "his" (asya), implying a

\footnotetext{
${ }^{120}$ Gonda 1963, pp. 91, 199.

${ }^{121}$ Kuiper 1996, pp. $239 \mathrm{ff}$.

122 Oberlies 2005, pp. 104-105

${ }^{123}$ Transl. following Kuiper (1996, p. 241): yád vā ghā satyám utá yán ná vidmá.

124 The "gandharvic path of Order" (gándharvìm pathyàm r rtásya) that Agni knows, according to RV 10.80.6, is interpreted by Geldner, and Lüders (p. 540 n. 2), as the correctly performed sacred formula, connected with the gandharva in 10.123.4 and 10.139.6.

${ }^{125}$ Prati- cakș- can mean "behold" as well as "display, make visible" (cf. examples in Böhtlingk and Roth s.v.; Grassmann s.v.); Geldner takes the word here in the latter sense ("seine Farben alle offenbarend"; cf. also Haas, p. 214), while Brereton and Jamison translate, "gazing upon all his forms". "Watching all forms" is, however, a figure used elsewhere in connection with celestial beings; thus RV 10.139.3 (viśva rüpábhí caște; of the sun-god) or 10.136.4, where the "long-haired" shaman, leaving his body, "flies through the air, beholding all forms" (antárikṣena patati viśva rūpávacákaśat).
} 
power over all creation ${ }^{126}$ - cf. the lavish praise of Viśvāvasu in AV 2.2 as "the heavenly gandharva, sole lord of the entire universe". ${ }^{127}$ Having his abode on top of the firmament, the gandharva occupies the function of transferring things - knowledge; the soma - from the celestial spheres to earth. ${ }^{12}$

In Middle Vedic texts, the knowledge possessed by the gandharvas is, of course, ritualistic. We have tales of gandharvas interfering in ritual or liturgical matters, correcting the performers on various points (MS 1.4.12; JB 2.126; SB 11.2.3.7, 11.5.1.14ff). The tale of the gandharva Ūrnāyu (PB 12.11.10; JB 3.76-7 ${ }^{129}$ ) is of great mythological interest here. It explains the origin of the aurnāyava liturgy, on which JB has the following to say:

Ūrnāyu the gandharva was lusting for apsarases. He saw this sāman (liturgy). He praised with it. Whomever he desired he approached and won over with it, [saying,] "This one!" and touching her. Thus, this is a wish-fulfilling sāman; this wish that he had, that wish came true for him. Whatever one may wish for, who praises with this sāman, that

\footnotetext{
${ }^{126}$ It may be noted that the all-god Rohita, the "ruddy" sun, is praised in almost identical terms in AV 13.1.11a-b: "Rohita stood upright upon the firmament, bringing forth all forms, the young sage" (ūrdhvó róhito ádhi náke asthād víśvā rūpáni janáyan yúvā kavíh).

${ }^{127}$ V. 1: divyó gandharvó bhúvanasya yás pátir éka. Also RV 9.86.36, where the gandharva "rules over the entire world" (víśvasya bhúvanasya rājáse); note, however, that the "gandharva" here is Soma.

${ }^{128}$ Kuiper (1996, pp. 249ff) has questioned the original celestial nature of the gandharva, arguing that it originates with the gandharva's occasional identification with Soma, or from a priestly "tendency to situate figures and events in heaven(s)" ( $p$. 251). Instead, he attempts to locate this kind of being within his own theoretical framework, which posits a primeval war between gods and asuras and a resulting formation of the ordered cosmos by the victorious gods. Supporting himself on RV 10.10.4 (where he interprets the gandharva of the waters and the water-maiden as the ultimate ancestors of gods and humans), Kuiper sees the gandharva as a primeval being existing before the cosmogonic battle, and ascribes its knowledge of things hidden (pp. 239ff, 253; cf. Kuiper 1979, pp. 94-5) to this fact; thus the three-headed gandharva of the (much younger) JB already knows the outcome of the war. I see very little support for the interpretation of the gandharva's abode as being the primeval waters from which the earth arose; his watery abode is frequently located in heaven. As Oberlies has pointed out, the notion of the gandharva as guardian of the heavenly soma - which, probably already in Indo-Iranian times, was located in the celestial sea - is well in keeping with its celestial nature (Oberlies 2005; 2012, pp. 76ff; cf. 33ff, 79ff).

${ }^{129}$ Cf. Caland 1970, pp. 237-38; 1931, pp. 298-99.
} 
wish comes true for him. As Ūrnāyu the gandharva saw it, therefore it is called aurnāyava. ${ }^{130}$

Then the story turns to a priest of the Angiras clan, named Kalyāna (PB) or Śvitra (JB). The Angirases were performing a sattra sacrifice for attaining heaven, but without result; searching for a solution, this priest came upon Ūrnāyu, "who was swinging amidst the apsarases"; ${ }^{131}$ as soon as the gandharva pointed to one of these, she became his. Ürnāayu taught him the wish-fulfilling liturgy, but had him promise not to claim himself as its discoverer (i.e., the one who had "seen" it through revelation). Kalyāna/Śvitra returned to the Angirases, and with the help of the new liturgy their sacrifice became successful; but when asked about its origin, Kalyāna/Śvitra declared himself to have discovered it, and so he was left behind when the others attained heaven.

We also hear of knowledge of future events. In one myth on the frequent theme of the war between gods and asuras, the former seek information from a three-headed (trisírșan-) ${ }^{132}$ gandharva who knows the outcome of the war, and what could change it (JB 1.125-27; variant in Baudhāyana Śrautasūtra $18.46^{133}$ ). By seducing the gandharva's wife, and then eavesdropping on their conversation, Indra obtained the desired information.

\section{Possessing women}

Mostly, however, the gandharvas transmit their esoteric knowledge through the mouth of a mortal - a person possessed by one of them. Thus JB 2.126, ${ }^{134}$ which tells of the wife of the brahmin Udara Śaṇ̣̣ilya, who was possessed by a gandharva (gandharvin̄in, lit.

\footnotetext{
${ }^{130} \bar{u}$ uñāyur vai gandharvo 'psaraso 'kāmayata. sa etat sāmāpaśyat. tenāstuta. tena yām yām akāmayata tām iyām iti yām yām evābhyamr'śat tām upait tām avārunddha. tad etat kāmasani sāma. etạn vai sa kāmam akāmayata, so 'smai kāmas samārdhyata. yatkāma evaitena sāmnā stute, sam asmai sa kāma ridhyate. yad ūrnāyur gandharvo 'paśyat tasmād aurnāyavam ity ākhyāyate.

131 apsarasām madhye preñkhayamānam.

${ }^{132}$ I assume that the three heads are indicative of omniscience, or ability to see on all sides; cf. the four-headed Brahmā of later mythology.

${ }^{133}$ Both texts translated in O'Flaherty 1985, pp. 87-90; JB 1.125-27 in Bodewitz 1990, pp. 71-2.

${ }^{134}$ Cf. Caland 1970, pp. 163-64; O'Flaherty 1985, pp. 91-3.
} 
"having a gandharva"). Through the wife, this gandharva warned the brahmin that the ekatrika sacrifice, which he intended to perform, was of a dangerous (darruna-) kind; thus greatly surprising the brahmin, who had told no one about the sacrifice. In AiB 5.29.2 and KB 2.8.13, we find a "maiden possessed by a gandharva" (kumāri gandharvagrhit $\bar{a}$ ) quoted among the authorities invoked in a doctrinal dispute (on whether the agnihotra-rite is to be performed before or after sunrise). The most famous cases of gandharva-possession are found in the $\mathrm{BA} U$, 3.3.1; 7.1: during a brahmodya-, or contest in metaphysical knowledge, Yaajñavalkya is on two occasions confronted by brahmins who have studied the Vedas in the house of Patañcala Kāpya. This man's wife and daughter were both possessed by gandharvas, who, through them, revealed knowledge on certain esoteric matters. Yājñavalkya is now questioned on whether he, too, possesses this knowledge (which he does).

What is considered spirit possession in pre-modern societies can, of course, often be identified as (especially mental) illness. The gandharvas and apsarases are indeed associated with madness, and so already in the AV. "The gandharvas and apsarases madden him who is about to go mad", states the TS. ${ }^{135}$ In AVP 1.29 the apsarases are unmädayișnavah, causing madness; they are "mind-bewildering" (manomúhah; $\mathrm{AV}(\mathrm{S})$ 2.2.5); they are also said to be fond of dice, and to preside over gambling $(2.2 .5 ; 4.38 ; 6.118 ; 7.109)$. "As gambling is repeatedly called an addiction, there seems to be a relationship with their causing madness"; ${ }^{136}$ and here one might also point to the wellknown Nala episode of the Mbh, where an obsessive gambling addiction is caused by possession by the evil spirit Kali. In $\mathrm{AV}(\dot{\mathrm{S}})$ 6.111.4, the apsarases, together with Indra and Bhaga, are called upon to cure a person from insanity (lit. "give back" his mind) ${ }^{137}$ in RVKh

\footnotetext{
${ }^{135}$ TS 3.4.8.4: gandharvāpsaráso vấ etám ún mādayanti yá unmádyaty.

${ }^{136}$ Oberlies 2009. In AV 6.130.1, the apsarases are implored to induce lovesickness (smará-) in a person; another kind of loss of mind, as it were.

137 "This fits well with the notion that madness was considered to be characterized by the mind leaving the body; and in order to become sane, it must be returned." (Zysk 2009, p. 188.) Cf. also Baudhāyana Śrautasūtra's (18.4.396; text and German transl. in Gotō 2000, pp. 100ff) version of the legend of king Purūravas and the apsaras Urvaśî, where the love-smitten apsaras stops the king's chariot by making an illusory hole appear in the road, then making it disappear, leaving the king wondering whether he is going mad (drpya-).
} 
4.8.3 we find the prayer (repeated in some younger texts ${ }^{138}$ ), "The intelligence that is with the apsarases, the mind that is with the gandharvas - that intelligence which is divine or human; may it enter me now!" 139 These lines are part of a longer prayer or spell for intelligence or wisdom (medhä-); apparently, the gandharvas and apsarases had the power to bestow as well as take away one's reason. ${ }^{140}$ It may be mentioned that the apsarases and their association with madness have often been compared to the nymphs of ancient Greece, ${ }^{141}$ who were sometimes said to cause madness by their mere appearance, but could also, in their more positive aspect, possess a person who then - as a nympholêptos - became endowed with great intellectual skill or inspiration, and the gift of prophecy. ${ }^{142}$ The question of a common origin of these beliefs is not easily answered; while there certainly do exist similarities between the apsarases and the nymphs - such as otherworldly beauty, and being inhabitants of trees and rivers - similar beings can be found also in the myths and folklore of non-Indo-European peoples. The association with madness, however, is certainly intriguing.

There also seems to be a more positive connection between gandharvas and apsarases, and mind or intellect. ${ }^{143}$ As we have seen, they are implored to give (back) a person's manas, and bestow medha upon him. In TS 1.7.7.1 and VS 30.1 (quoted in ŚB 5.1.1.16), we find the line, "May the heavenly gandharva, purifier of thoughts, purify our thoughts". ${ }^{144}$ In RV 10.11.2a-b, "the gandharvī, the water-maid" (gandharvì́r ápyā ca yósaṇā), is invoked by the poet to "protect my mind" (pári pātu me mánaḥ); in 10.139.5, Viśvāvasu, the "heavenly gandharva" (divyó gandharvó; obviously identical with the one of TS

\footnotetext{
${ }^{138}$ I refer to Bloomfield 1906, p. 343. The verses are later used for invoking wisdom to enter a Veda-student; cf. Gonda 1975, p. 168.

${ }_{139}$ yā medhà apsarassu gandharveșu ca yan manah/daivī yā mānuși medhā sā mām àviśatād iha.

${ }^{140}$ Elsewhere in this prayer, this wisdom is called gandharvajuștām, "enjoyed by the gandharvas". While several other divinities are invoked to bestow it, it is, notably, said to actually be among the gandharvas and apsarases - not with any other deity. This indicates, I think, that these beings could have possession of a person's mind and intelligence, and seize or withhold it at will.

${ }^{141}$ Cf. e.g. West 2007, pp. 284-92; Oberlies 2009.

${ }^{142}$ Cf. Connor 1988; more generally, e.g., West 2007, p. 287.

${ }^{143}$ Cf. Wijesekera 1994a, p. 189-90.

144 divyo gandharvaḥ ketapūh ketạ̣ nah punātu.
} 
and ŚB), is invoked for similar purposes: "to stimulate our thoughts, to aid our thoughts" (dhíyo hinvānó dhíya ín no avyāh).

As appears from the cases cited earlier, the gandharvas possess - as it seems, exclusively - women. ${ }^{145}$ This brings us to the subject of spiritpossession studies in comparative anthropology and religion. It is a well-known fact, albeit variously interpreted, that women are particularly (though by no means exclusively) prone to possession by spirits or deities; this is, or has been, the case in culturally unrelated societies around the world. I. M. Lewis' study of possession cults, ${ }^{146}$ which is probably the most widely read work to date on the subject, argued that spirit possession is most prominent in marginalized groups (among which women are usually one); individuals belonging to these groups may, according to Lewis, raise their status and make their voices heard by letting themselves become the instruments of spirits or deities, who are believed to speak through them. As such, possessed persons often become the center of local cults, and their words carry great authority. While Lewis' theory is still widely influential, there are, of course, others; not least the high occurrence of possession among women has been the subject of a fair amount of theory-construction in a variety of fields (psychology, gender studies etc.). ${ }^{147}$ Thus, traditional gender roles, which make women the "passive", "receiving" sex, have been invoked as one important reason why women are entered by spirits and become their passive instruments. Then there is the sexual aspect: the fact that the possessing spirits and deities are mostly of the male gender, and the possessed females are thought of as objects of their enjoyment. ${ }^{148}$

\footnotetext{
${ }^{145}$ Though the apsarases are frequently said to cause insanity, I cannot find any explicit reference to possession by them. Nonetheless, possession was most likely thought to be the means by which they induced madness in people. If so, the question arises as to whether they only possessed men, like the gandharvas possessed women. As the gambler or kitavá- apparently was one of their main targets, this seems to have been the case; for the kitavá- as typically a young man, see Falk 1986, p. 99. The gambling hall or $s a b h \bar{a}-$ is well known to have been an exclusively male area.

${ }^{146}$ Lewis 1975.

${ }^{147}$ See, for example, Sered 1994, Keller 2002, Schmidt and Huskinson 2010. Lewis' theory still remains one of the most valuable, despite the criticisms levelled in some of these works.

${ }^{148}$ For the erotic undertones of possession, and the belief that spirits mainly possess persons of the opposite gender, cf. Lewis, pp. $58 \mathrm{ff}, 84$.
} 
Both these kinds of approach - the socio-anthropological and the psychological - seem to be applicable to the Vedic situation, as far as we can glimpse the beliefs and realities behind the legends. The wife and daughter of Patañcala Kāpya in the BĀU are clearly in the center of a kind of possession cult, filling the function of oracles and being questioned on esoteric matters. ${ }^{149}$ Whether these cases are actual historical reality or not is unimportant; what matters here is that such cults obviously were in existence. An actual case of spirit possession appears, on the other hand, to be referred to in the AiB and KB, where a certain "maiden possessed by a gandharva" is cited as an authority on matters of doctrinal dispute (even though the view of the maiden/the gandharva on these matters is ultimately rejected by the authors). It seems clear that possession by gandharvas made it possible for certain women to take part in learned discussions from which they were otherwise barred; such as brahmanical disputes on the subject of ritual.

At the same time, it can't be denied that there is a sexual dimension to the possession by gandharvas - beings who are so often referred to as "fond of women" (strikkāma-). We have already quoted AV 8.6.19, where mention is made of the "women-sharing (strîbhāga) gandharvas" who cause the embryo in the womb to die; this refers, most likely, to a fatal sexual enjoyment of pregnant women. ${ }^{150}$ Very likely, this enjoyment was thought to take place through possession; we have already referred to the fact that demon possession was believed, in Vedic as well as younger times, to be the cause of miscarriage. Indeed, there seems - judging from the texts - to be no better explanation as to why gandharvas only possess women. (Only in much later texts, like the medical compendia of Suśruta and Caraka, do we meet with possession by gandharvas also of men or boys. ${ }^{151}$ )

\footnotetext{
${ }^{149}$ Cf. Smith 2009, p. 230: "Did Bhujyu Lāhyāyani simply wander into his friend Patañcala Kāpya's house on a couple of occasions and discover his wife and daughter occupied with housework, possessed by gandharvas, ready to take questions? This is highly unlikely. More likely, given the evidence of later texts, a ritual was taking place and Bhujyu Lāhyāyani showed up for the occasion."

${ }^{150}$ Kuiper $(1996$, p. 245$)$ points out that the designation as strik $\bar{a} m a-$ seems to occur only in the context of the myth of the soma-barter. While this may be true, the lustful nature of these beings is well in keeping with atharvavedic and later materials.

${ }^{151}$ Suśruta Samphitā, 6.60.10, declares the symptoms of gandharva-possession to be laughing and dancing, and a fondness of singing, perfumes and garlands; thus, "in gewisser Übereinstimmung mit dem Grundcharakter der Gandharven”, as Hillebrandt
} 
Spirit possession never became an integrated part of the brahmanical religion, nor in the Buddhist or Jainist traditions; possession-cults were mainly confined to the more popular religious life, as a consequence of which possession has long been a neglected subject in the historical study of Indian religions. Some of the lacuna has recently been filled by Frederick M. Smith's extensive survey of possession in South Asian religions, from Vedic to modern times. ${ }^{152}$ Dealing with questions of comparative anthropology, Smith notes that possession has occurred especially in women and children; this holds for almost all the epochs treated, from the gandharva possession of Vedic times to classical "Hindu" beliefs and even up to the present day. ${ }^{153}$ Of interest here is also his survey of the terminology of ancient Indian spirit possession, where two terms in particular are singled out as the most prominent ones: formations from the verbal root viś- "to enter" (with prefixes pra- or $\bar{a}$-), and the verbal root grh- "to grasp, to seize"; the former occurs in connection with more "positive", often ritually controlled forms of possession, in which a deity "enters" a human being (though pra- viś- usually refers to possession independent of the possessed person's will), while cases where grh-is used are of a more sinister nature: the possession is here caused by spirits or demons of disease or madness, who forcefully take control over ("seize") a person's body. From this root is derived the word graha-, referring to demons of sickness (several times already in $\mathrm{AV}) .{ }^{154}$ It is formations from grh- that are used in depictions of gandharva possession; thus the gandharvagrhit $\bar{a}$ - ("seized by gandharvas") women in $\mathrm{AiB}, \mathrm{KB}$, and $\mathrm{BA} U .{ }^{155}$ This confirms the general impression from the source-texts that possession caused by gandharvas was an unwelcome thing - usually leading to insanity -

(1987, p. 183) noted. In Caraka Saṃhitā, 6.9.21.4, it is rather the gandharva-like character of a person that causes the possession: "The gandharvas attack a person of pure behavior who is fond of hymns of praise, singing, and musical instruments, who is fond of other men's wives, perfumes, and garlands, generally on the twelfth and fourteenth lunar days" (quoted from Smith 2009, p. 409).

${ }^{152}$ Smith 2009.

${ }^{153} \mathrm{On}$ spirit possession and women, see esp. pp. 68-75, 430ff, 545ff; on gandharva possession, pp. 224-32.

${ }^{154} \mathrm{Cf}$. Smith, Index, s.v. graha, gráhì.

${ }^{155}$ The word grhita- is, however, not used in the story of Yavakrī and the apsaras (pace Smith, p. 228); nor is any other word from the same root. 
though it could be used to the advantage of the husbands or relatives of the possessed woman (divination).

Such divination rituals are well attested in somewhat later times. Of special interest in this connection is Smith's study ${ }^{156}$ of a medieval tantric ritual of oracular possession, called svasthāveśa-, or simply praśna-, "questioning" (prakrit pasina-; later, falsely resanskritized as prasen $\bar{a}-$ ). In this ritual, a spirit (itself often called prasen $\bar{a}$ ) is invited to enter an object, a body-part, or a person usually a young girl or a child; the spirit is then questioned on future events. In one form of the ritual, a maiden serves as an oracle, while being in a state of trance and, sometimes, looking into a mirror. ${ }^{157}$ According to Hemacandra, ${ }^{158}$ a deity (devatā) is made to enter the mirror, through which it reveals the desired knowledge to a young girl (kanyā) looking into the mirror. The question answered through this divination practice is here, specifically, said to concern the time of one's death. Now, while this and the other texts collected by Smith all belong to medieval times - the oldest being from the second half of the first millennium C.E. - it may be noted that the Sāmavidhāna Brāhmaṇa, 3.8.1ff (one of the very youngest Brāhmaṇa texts, but certainly older than any of the tantric texts treated by Smith), prescribes a very similar ritual, with the purpose of preventing one's rebirth after death. Here, a kanyā, with plaited hair (śikhandini $\bar{i}^{-}$) and noose in hand, serves as oracle in a preparatory, nightly ritual; she reveals to the person wishing not to be reborn the year, half-year, season, month, etc., down to the day or night and muhürta when he is going to die, thereupon to be reborn (3.8.3). With this knowledge, that person may then, using spells and penance, avert the rebirth awaiting him, and instead attain the realm of air ( $\bar{a} k \bar{a} s \dot{s} a-)$ after death. The Dīgha Nikāya, 1.26, in a list of divinatory and magical practices prohibited for Buddhist monks, mentions kumārīpañha-, "questioning a young girl"; the word appears between ādāsapañha-, "questioning a mirror", and devapañha-, "questioning a god", and obviously refers, as Rhys Davids (following Buddhaghosa) translated it, to "Obtaining oracular

\footnotetext{
${ }^{156}$ Smith, chap. 11.

157 "One might argue that this is not possession of the girl; rather, it is an allied divinatory practice. However, in South Asia, people, especially women, are considered possessed if they transmit such messages in trance states." Ibid, p. 431.

${ }^{158}$ Yoga Śāstra 5.173-6; quoted in Smith, p. 431.
} 
answers from a girl possessed" ${ }^{159}$ In devapañha- too, a girl serves as the oracle, according to Buddhaghosa's $5^{\text {th }}$ century commentary; but here, it is a temple prostitute (devadās $\bar{\imath}$ ), while the kumāri is said to be of good family and respectable. Using young girls - usually in a state of trance, but perhaps also insane ones - as oracles was, as it seems, a long-standing tradition in ancient India. ${ }^{160}$

Now, it may be suggested - but this is only a speculation - that the association with possession could explain some of the more prominent traits of gandharvas; such as their fondness of garlands, ornaments, scents, music and singing. Lewis gives numerous examples of possession cults centered around women, where "the spirit" speaking through the possessed woman demands luxuries such as clothes and ornaments; song and music are frequently part of the "treatment" of the possession. The often very specific requests of the spirits are believed to mirror the particular nature of these beings; the Islamic jinns, for instance, were in Somalia "thought to be consumed by envy and greed, and to hunger especially after dainty foods, luxurious clothing, jewellery, perfume, and other finery" ${ }^{161}$ In the medical compendia of Caraka and Suśruta, people possessed by gandharvas are indeed said to be hankering for the same things as these beings: garlands, scents etc. ${ }^{162}$ The youthful and careless nature of these deities, to which we will return, is, however, also likely to have contributed to these conceptions.

\footnotetext{
${ }^{159}$ Cf. also the entry under this word in Rhys Davids and Stede 1952 [1921].

${ }^{160} \mathrm{Cf}$. possibly the female vipraśnikās consulted by king Dhrortarāștra Vaicitravīrya (Kăthaka Saṃhitā 10.6) to find out the cause of a disaster that has befallen his domain (they reveal that it is caused by the black magic of an insulted brahmin). While we learn next to nothing from the text about these vipraśnikās, it is remarkable that women seem to have been employed as psychics at the, otherwise male-dominated, Vedic royal court.

${ }^{161}$ Lewis p. 75.

${ }^{162}$ See n. 148 above. Similarly in Viṣnudharmottara Purāṇa 1.231.36ff, quoted by Thite (1987), p. 58. Noting that this passage prescribes music as part of the possessed person's treatment, and that similar "cures" for possession are to be found in other cultures, Thite suggests a connection between the gandharva's association with music, and his possessing people. Smith (p. 230) proposes to see gandharva-possession in "a context ... in which music was played as part of a ritual to abet the onset of trance states, such as possession", but provides no further basis for this assumption.
} 


\section{Apsarases and men: fleeting relationships and gandharvic jealousy}

The conception of "women-desiring" gandharvas seizing females and, at will, revealing sacred knowledge through them, brings us to what may be the core of the Vedic mythology around gandharvas: there takes place a kind of exchange during the possession, wherein the gandharvas enjoy mortal women who are often married, but, on the other hand, may provide their husbands or relatives with esoteric knowledge. This is, more or less, the same kind of exchange as that which takes place in the myth of the bartering of soma: there, a sacred and powerful substance is traded by the gandharvas for Vāc - who, sure enough, embodies the Vedic sacred formulas, but is desired by the strik $\bar{a} m a$ - gandharvas solely as an object of sexual enjoyment. For the somewhat more pious gods, however, her presence is of the highest importance, and so they have to win her back. The case is similar in the story of Ūrnāyu, who, knowing a wish-fulfilling liturgy capable of ensuring mortals of heaven, himself put it to no better use than for obtaining women. The gandharva was, as we have seen, thought to dwell in the highest celestial spheres, where he was in direct contact with sacred substances such as soma, and in possession of superhuman knowledge; this heavenly realm was, however, thought of merely as a depository, from which these things were seized by the gods in ancient times (e.g., in the various myths of the soma-robbing, finding the hidden Agni etc.), and from which they may be brought to earth by the gandharvas, who, as intermediaries between heaven and earth (Oberlies), bring the sap to the soma plant, embryos to mortal wombs, and sacred knowledge to certain humans. The gandharvas themselves, being merely the keepers and carriers of these things from the "depository" realm, seem to make no actual use of them - except, sometimes, for the sake of enjoying women. A rather clear example is the primeval war between gods and asuras, as told in some versions in the JB. ${ }^{163}$ Here, it is related that "the Kali gandharvas" 164 did not take part in this war, maintaining a neutral stand (antasth $\bar{a}$-); yet after the war asked the victorious gods for a share in the conquered worlds, as

\footnotetext{
${ }^{163}$ Cf. translations in O'Flaherty 1985, pp. 86ff; Bodewitz 1990, pp. 71-2, 86-7.

${ }^{164}$ Also mentioned in AV 10.10.13; what makes them distinct from other gandharvas is not clear.
} 
they had been supporting their side in their minds (1.154-55). Then there is the story of the three-headed gandharva who knew the outcome of the ongoing war, and how to change it, yet did not enclose this information to the gods (nor to the asuras), who had to obtain it through trickery (1.125-27). The knowledge or sacred substances possessed by the gandharvas are, so to speak, not "activated" or used to their full potential, until they leave these deities.

Interestingly, a woman appears in an intermediary function also in the tale of the three-headed gandharva: the gandharva's wife, who is seduced by Indra in a successful attempt to obtain the desired information; here it is, thus, the gandharva who is cuckolded, not the other way around. This tale throws some further interesting light on the gandharvas' relationships with women. Of the three-headed gandharva it is said that "he had a boat-mansion ${ }^{165}$ floating about in the waters". 166 "The waters" are apparently the heavenly ocean, the traditional home of the gandharvas; $\bar{a} p a h$ or its locative form, apsu, being often used, without further qualification, to denote the celestial waters. ${ }^{167}$ Now, a reason is given for the gandharva's unusual choice of abode: although the readings of the manuscripts are corrupt, Hoffmann ${ }^{168}$ is no doubt right in his emendation to sa herșyur āsa"he was jealous" (1.125). Hoffmann supports this reading on a parallel

\footnotetext{
${ }^{165}$ The version in Baudhāyana Śrautasūtra 18.46 has a "golden boat" (hiraṇmayyā nāvayā; O'Flaherty's rendering "a golden palace" must be a slip).

166 tasya hāpsv antar naunagaram pariplavam assa. This is one of the earliest occurrences of the word nagara-, later meaning "city", though cities may still have been unknown at the time of the text's composition; still, the compound nau-nagarahas been rendered as "ship-town" (Bodewitz), "boat-city" (O'Flaherty 1985), "Schiffsburg" (Hoffmann 1960, p. 7). Kuiper (1996, p. 238), however, gives "houseboat", commenting: "In Dravidian, from which nagaram has doubtless been borrowed ... nakar 'town, city' originally denoted a single building: a temple (Tamil), a palace (Old Tamil, also Telugu nagaru) and even a 'house, abode, mansion' (Old Tamil, in Akanānūuru 15) ... The Old Tamil Sangam literature dates from the first centuries A. D., and naunagaram, lit. a 'house on a boat', reflects the older meaning of nakar in Dravidian." Personally, I suspect that nagara- in the text concerned denotes something bigger - a mansion or a palace - as the proper name Nagarin occurring in some Brāhmanas would seem rather pointless if simply denoting a "house-dweller."

${ }^{167}$ Cf. e.g. JB 1.292: "the lightning in the waters" (vidyud apsu); JUB 1.34.4 (the sun and moon being seen in the waters, apsu); SB 7.5.1.8 (the sun giving heat deep in the waters).

${ }^{168}$ Hoffmann 1960, p. 7.
} 
in JB 3.197, where it is said of the demon ${ }^{169}$ Asita Dhāmnya that he protected his daughter's virginity in a similar way: "Now, Asita Dhāmnya was jealous (ìrşyur āsa). He had a palace in the air." ${ }^{\prime 170}$ (As in the case of the gandharva's wife, these efforts at protection are ultimately frustrated.) That the palace is said to be in the sky would seem to support our assumption that the gandharva's "boat-mansion" is floating in the heavenly waters; one is reminded of the aerial "cities of the gandharvas" (gandharva-pura- or -nagara-), a kind of fata morgana often mentioned in later literature. ${ }^{171}$

The gandharva of the tale thus has a jealous nature, and seeks to guard his wife at any costs. That this is not an individual characteristic of this specific gandharva may be established through a comparison with JB 2.269-72; the story of the brahmin Yavakrī. ${ }^{172}$ This man used to take advantage of his brahmanical status and power for having whatever woman he wanted; "Whomever he called upon would make love to him and then die; and who did not make love to him would also die". ${ }^{173}$ (This easily reminds one of Ürnāyu's ability, though in a more sinister form.) One day he called in this way upon the wife of the brahmin Yajñavacas Rājastambāyana. When her husband later found her ornamented and crying, prepared to make love to Yavakrī and then die, he performed a fire sacrifice; and from the oblation rose an apsaras in the likeness of the wife. She was sent to Yavakrī in the wife's place. As they were about to have intercourse, the apsaras started giggling and showed the brahmin the hairy soles of her feet (lomaśau ... adhastāt pād $\bar{a} v$ ), thus revealing her true nature (cf. the "hairy boy" of AV 4.37.11, donning a pleasant guise before

${ }^{169}$ An "Asita Dhānva" is mentioned as the leader of asuras in ŚB 13.4.3.11; one line in JB 3.197 implies that his kin are rakșases.

${ }^{170}$ atha asito dhāmnya ìrșyur āsa. tasya hāntarikșe prāsāda āsa. For the entire story, see Caland 1970, pp. 269-70; O'Flaherty 1985, p. 95.

${ }^{171}$ See references in Hopkins 1915, p. 157; Böhtlingk \& Roth 1855-75, s.v. gandharvanagara, gandharvapura. The term does not appear in Vedic, though the Șaḍviṃśa Brāhmaṇa, 6.8.13, mentions a "palace in the sky" (äkāśe rājakulaṃ) in a list of bad omens; Sāyana glosses this as gandharvanagara-. Might the "golden palace" (hiranyavimitāni) of the gandharvas and apsarases, appearing before Purūravas in ŚB 11.5.1.11, be related to the later conception?

${ }^{172}$ Cf. Caland 1970, pp. 190-94; O'Flaherty 1985, pp. 105-11. (The version edited and translated by Caland is somewhat shorter than the one in Vira and Chandra's edition, and leaves out some of the passages discussed here.)

${ }^{173}$ sa ha sma yām acchābrūte yā ha smainam kāmayate mriyate ha sma, yo ha smainam na kämayate mriyata u eva. (2.269.) 
women ${ }^{174}$ ); meanwhile, Yajñavacas had been performing another offering, this time producing "a jealous (i $r$ ssyu-) gandharva with an iron axe in his hand" ${ }^{175}$ "He [Yajñavacas] said to him, "That wife of yours has gone to Yavakrī! "'; ${ }^{176}$ and so the gandharva went there, finding the brahmin in bed with the apsaras. Terrified, Yavakrī asked him about some penance (prāyaścitta-) to atone for his offense; the gandharva told him to cut the heads off all his and his father's cattle before sunrise. Yavakrī did not survive the night; he was, according to the text, either killed by the gandharva, or by a local carpenter who wanted to put an end to the outrageous cattle-slaughter. There are a few hints in the text that seem to imply that Yavakrī was in fact possessed, or perhaps was so in an earlier version; people seeing him behead his cattle are said to have told each other, "Yavakrī has gone insane!" (adrpad yavakrīr) - gandharvas and apsarases were, of course, believed to be responsible for mental illness in people - and his father then replied that his son seemed to be "driven by gods" (deveșito). ${ }^{177}$

What is important for the present discussion is the fact that the gandharva is described as $\bar{i} r s y u-$, jealous, and that it is jealousy that drives him to take Yavakrī's life; apparently, Yajñavacas could not simply produce a gandharva and command him to kill Yavakrī, but had first to make his enemy cohabitate with an apsaras, thereby provoking the gandharva's wrath.

The motif of the gandharvas' jealousy is also present in the famous legend of Purūravas and the apsaras Urvaśí, as told in the ŚB

\footnotetext{
174 Though references to an ugly, "true" form of the (usually handsome) gandharvas and apsarases are rare, enticing and seductive beings of folklore often are, partly or at some times, ugly or hairy; even when appearing in a beautiful guise, lower parts of the body (which are hidden under clothes) are said to be hairy. Thus the forest nymph of Scandinavian and German beliefs is depicted as a beautiful woman bent on seducing wanderers, but can be recognized by her having furry legs, a tail, or goat's feet (Mannhardt 1875, p. 95 n. 1, 128ff). In Arabian and Jewish legend, the beautiful queen of Sheba, being the daughter of a jinni and a mortal man, was recognized as such by king Solomon, who tricked her into lifting her skirts and revealing her hairy feet (see, e.g., al-Tha'labī and al-Kisā'̄i, transl. in Lassner 1993, pp. 188ff, 208ff).

${ }^{175}$ hāyahküțahastam gandharvam ìrsyum (2.270). What follows is part of the motif of "the shattered head" (Witzel 1987), wherein an offender is threatened with having his head split open by a supernatural being. ${ }^{176}$ [a] sau te jāyā yavakrīyam abhyagāt.

177 The very same word is used for the possessed muni- of RV 10.136, for which see more below.
} 
(11.5.1). This is, basically, the traditional tale of a mortal man espousing a supernatural woman, only to lose her after breaking some taboo; ${ }^{178}$ but it also appears to reveal much regarding the nature of the gandharvas and apsarases. The "taboo" in this story is laid down by the apsaras when she agrees to live with Purüravas: if he would ever show himself naked to her, she would leave him. ${ }^{179}$ When Urvaśî had lived with Purūravas for a while, and had become pregnant, "the Gandharvas said to one another, 'For a long time, indeed, has this Urvaśi dwelt among men: devise ye some means how she may come back to us." "180 In the night, they robbed away a sheep that was tied to Urvaśî's bedstead; the apsaras called for Purūravas to go after the thieves, and as he hurried out in the night without putting on any clothes, the gandharvas caused a lightning-flash to light up the place and reveal the undressed Purūravas to his wife. (This event is already alluded to in v. 3 of the dialogue between Purūravas and Urvaśí in RV 10.95.) The apsaras consequently disappeared. Purūravas, having "wandered all over Kurukșetra" in his sorrow, eventually came upon his lost wife as she and other apsarases were sporting in a pond in the shapes of water-birds; after several attempts at persuading her to return to him (the dialogue is derived from RV 10.95), he is told to return to the place after one year has lapsed. When he returns, a golden palace (hiranyavimitäni) has appeared on the spot; Purūravas is there met by Urvaśī, who declares,

'To-morrow morning the Gandharvas will grant thee a boon, and thou must make thy choice.' He said, 'Choose thou for me!' She replied, 'Say, Let me be one of yourselves!' In the morning the Gandharvas granted him a boon; and he said, 'Let me be one of yourselves!' 181 (11.5.1.12, transl. Eggeling.)

The gandharvas then instruct Purūravas on how to perform a firesacrifice, which makes him one of them and allows him to reunite with his wife.

\footnotetext{
${ }^{178}$ Cf. Aarne-Thompson No. 400: "The Man on a Quest for his Lost Wife."

179 "Originally", it may have been the apsaras who was not to be seen in her true form, as comparative folklore (e.g., the story of Cupid and Psyche) suggests; thus Oldenberg 1894, p. 253, Keith 2007, p. 183.

${ }^{180}$ ŚB 11.5.1.2, transl. Eggeling (transliteration modernized).

${ }^{181}$ gandharvā vai te prātar varam dātāras tạn vrnạāā iti tam vai me tvam eva vrṇiṣveti yuṣmākam evaiko 'sānīti brūtād iti tasmai ha prātar gandharvā varạ̣ daduh sa hovāca yușmākam evaiko 'sānīti.
} 
The gandharvas here appear as a group that does not want their women to establish long-term relationships with outsiders, or at least not with mortals. ${ }^{182}$ (Though preventing such relationships must have been quite a task, considering the well-known licentiousness of the apsarases.) They break up Purūravas and Urvaśî's relationship because they think she has dwelt too long among mortals; when the apsaras finally gives in to Purūravas' pleadings and agrees to take him back, he is told that he first has to become one of the gandharvas. Even if the story's happy ending, which is not alluded to in RV 10.95, should be considered a late, brahmanical addition reflecting the priestly sacrificial ideology, ${ }^{183}$ it nonetheless appears to tell us something about the conception of the gandharvas: though both they and (at least in post-Vedic mythology) the apsarases frequently indulge in fleeting relationships with humans, they seem to marry exclusively within their own group. This is well in keeping with the epic legends which have apsarases consorting for a while with mortal kings and heroes, only to later abandon them and the children that usually are the outcome of the relationship. Only in paradise, it seems, are the pious deceased - and especially heroes slain in battle - actually married to apsarases, ${ }^{184}$ though this theme, too, may be a late development; it appears first in late Vedic texts. ${ }^{185}$ The case of Purūravas is similar: he is not accepted as a proper husband of Urvaśi until he himself has become a gandharva and joined their numbers in heaven.

A late expression of the belief in the gandharvas' dangerous jealousy is found in the Virätaparvan - the fourth book of the Mahābhārata. ${ }^{186}$ As the five Pānd d̦ava heroes and their wife Draupadī, during their last year in exile, live disguised as servants at the court of king Virāta, Draupadī - who has donned the guise of a maidservant (? sairamdhri-) and, pretending to be unmarried, worries about her beauty attracting men - seeks to scare away suitors by claiming to be

${ }^{182}$ But apparently not with several gandharvas, as their relationships are usually promiscuous; see below.

${ }^{183}$ Cf. Oldenberg 1894, p. 254 n.1; Keith 2007, p. 183; for a different opinion: Geldner in Pischel and Geldner 1889, p. 259.

${ }^{184} \mathrm{Cf}$. the materials in Hara 2001; cf. Hopkins, pp. 161, 163. Note that in Mbh 11.26.13, the slain heroes are said to join the gandharvas.

${ }^{185} \mathrm{It}$ is first foreshadowed in JB 1.42, 44, and Kaușītaki Upanișad 1.4.

${ }^{186} \mathrm{Cf}$. van Buitenen 1978 for a complete translation. 
married to five bellicose gandharvas. These supernatural husbands will not tolerate any man making approaches to her:

I am not to be obtained by Virāta, nor by any other man at all. I have for husbands five youthful gandharvas, O splendid one, sons of a certain glorious gandharva king. They always protect me; so I am dangerous to approach ... The man who covets me like other, lowborn women, he will that very night enter another body [i.e., die]. ${ }^{187}$

Later on, she is forcefully approached by the king's commander, Kicaka, who doesn't heed her warnings about the wrath of the gandharva husbands. She eventually has one of her real husbands, Bhima, secretly kill the harasser, squeezing him into a ball with his bare hands; Draupadī then declares to everyone that this was done by the jealous gandharvas. After Kīcaka's vengeful kinsmen are similarly slain by Bhīma for assaulting Draupadī, the king wants her to leave the court for everyone's safety, but has his queen telling her this, not daring to do so himself - as a man - for fear of the gandharvas $(4.23 .8-10)$.

\section{Weddings and initiations: the gandharva and rites de passage}

A similar struggle for women as seen in these tales may be pointed out in the myth of the bartering of the soma: the gandharvas ask the gods for Vāc - not in her function as goddess of sacred speech, but simply as an object of enjoyment - but are made to promise (in the ŚB version) not to restrain her against her will (as they may have been prone to do with their women; cf. the three-headed gandharva in JB). The competition for her ends with their defeat and Vāc's return to the gods. There is some evidence that connects this myth with the notion of the gandharvas' right to a girl before her marriage, and their unwillingness to let go of her even after the wedding. The late Vedic wedding-hymn recorded in the Kāṭhaka Gṛhyasūtra has some stanzas that are based on the myth, speaking of the goddess who is being evoked by two contending parties:

\footnotetext{
${ }^{187}$ Mbh 4.8.27-28, 30: nāsmi labhyā virātena na cānyena kathạ̣ cana/ gandharvāh patayo mahyam yuvānah pañca bhāmini// putrā gandharvarājasya mahāsattvasya kasya cit/ rakșanti te ca mām nityam duhkhāāārā tathā nv aham// ... yo hi mām puruṣo gṛdhyed yathānyāh prākṛtastriyah/ tām eva sa tato rātrị̣ praviśed aparāṃ tanum $/ /$.
} 
We, both gods and gandharvas, call upon you together in contest. Go to those of them (us) whom you desire, Sarasvatī!

(The goddess:) "I turn to the gods, I desire those who sing. Women desire him who sings, not the one who utters a bráhman." 188

The gandharvas and apsarases are mentioned throughout the hymn; in the half-verse immediately preceding the verses quoted (v. 18c-d), the singer (that is, the bridegroom) refers to his own "gandharva with the head" - the male organ - which wins over the bride for him: "May the gandharva with the head make you stay with me."

The Vādhūla Śrautasūtra's account of the contest for Vāc follows, word for word, the version given in TS 6.1.6.6; the only difference being that it includes four stanzas from the abovementioned wedding-hymn. This is the more interesting as the prosetext from TS makes explicit mention of marriage. I quote here the relevant part of the Vādhūla text:

The gandharvas uttered a sacred formula (brahman); the gods sang. "Those people who existed formerly", was the sacred formula the gandharvas uttered; "Those who formerly brought weal to them - for them the gandharva with the head gave heat before the gods. Those people who existed formerly, before the former ones - the one with the head, the son of Subhrū (?), also gave heat for them before the sun." "The one first choice of women", was the song ( $g \bar{a}$ th $\bar{a}-)$ that the gods sang, "in which is found this entire world - that song will I sing today, that which is the highest glory of women. Support this one, fortunate Sarasvatī, rich in rewards! We sing to you, prior to all existence!" She turned to the singing gods. Therefore women desire one who sings; women become desirous of him who knows thus. ${ }^{190}$

\footnotetext{
${ }^{188}$ ubhaye tvā devagandharvāh sadhryañco vihvayāmahel teșām yatarāv kāmayase tān abhyehi sarasvati// abhyāvarte 'ham devān gāyatah kāmayāmahel gāyantam striyah kāmayante na tathā brahmavādinam//. (19-20; text from Caland 1929, p. 311.) 189 mürdhanvắm̆s tvā gandharvó má̀m abhiniyacchatu.

${ }^{190}$ Text and discussion in Caland 1928, pp. 157ff: brahma gandharvā avadann agāyan deva, ye ha pūrve janā āsur iti brahma gandharvā avadan yebhyah pūrvevaho hitam/ sìrșanvāims tebhyo gandharvah puro devebhya ätapat// ye ha pūrve janā āsuh pūrve pūrvaratarebhyah/ mūrdhanvāmั tebhyah saubhruvah purā sūryād utātapad iti yā strīnām varyetīti gāthām devā agāyan yasyām viśvam idạn jagat/ tām adya gāthām gāsyāmi yā strīnām uttamam yaśah/l sarasvati predam ava subhage vājinīvati/ tām tvā viśvasya bhūtasya pragāāamasy agrata iti. sā devān gāayata upāvartata tasmād gāyantam striyah kāmayante, kāmukā enam striyo bhavanti ya evam veda.
} 
The TS text concludes: "So if there is in a family one person who knows thus, men give their daughters in wedlock to that family, even if there be other (wooers) in plenty." 191

All these stanzas appear, though in a different order, in the hymn in KGS. While the Vādhūla text presents some of them as a (profane) song, gāthāa, and the others as a bráhman or sacred formula, they are in fact all, as Caland noted, ${ }^{192}$ part of the same wedding-song. $\mathrm{He}$ also pointed out ${ }^{193}$ that the association of the myth with weddings appears already in MS 3.7.3, which concludes its version of the story with the following words:

Therefore a song is sung at a wedding. Therefore one who sings is dear to a woman. That is why one knowing thus, singing a song, marries [lit. "grasps the hand (of the bride)"]. Then the two (the married couple) age together. They live their whole lifespan. They do not get into difficulty. ${ }^{194}$

While this dimension of the myth is no doubt secondary, it is thus, nonetheless, very old. It appears from the wedding-hymn that the bride was thought of as the object of a struggle between two parties, here referred to as gods and gandharvas. We may point here again to the belief recorded in AV 14.2.9, that the gandharvas and apsarases, hiding in trees, sought to attack the wedding-procession. Vasilkov ${ }^{195}$ has suggested that this notion may be connected with a custom known from several societies, in which, at a wedding, a mock-battle between two contending parties is fought over the bride. There would, in that case, have been people present who impersonated the gandharvas and apsarases. Vasilkov believes that these people are to be recognized in the "long-haired people" (keśíno jánā) and "young sisters" (jāmáyo ... yuvatáyo), dancing in the bride's house and wailing over her departure, who are mentioned in the same hymn (14.2.59-61). These have some characteristics in common with the gandharvas and apsarases - youthfulness, dancing, long hair (for which see below).

${ }^{191}$ [a] tho yá evám vidván ápi jányeșu bhávati tébhya evá dadaty utá yád bahútayāh. (TS 6.1.6.6, transl. Keith.)

${ }^{192}$ Caland 1929; 1928, p. 159.

${ }^{193}$ Caland 1928, p. 158. Cf. Ludvik 1998, p. 349.

${ }^{194}$ tásmād vivāhé gáathā gìyate tásmād gá̀yant striyánh priyás. tád yá evám vidván gáthām gấyan hastám grhṇáti sám hí jíryatah sárvam ắyur ito nấrtim nìtas. (Transl. Ludvik, ibid.; brackets mine.)

${ }^{195}$ Vasilkov 1990, p. 395. 
Who, then, are these people? Vasilkov's study suggests a connection between the gandharvas and apsarases of mythology and age-set groups of young boys and girls who have not yet entered the adult, married life. The bride would have belonged to such a group before her marriage; thus the notion that she used to be married to the gandharva(s). This assumption may find some support in the stanzas 14.2.59-61, which seem to imply that the bride used to be one among the "dancing" youths who are now wailing:

If these long-haired people have danced together in your house, doing evil through wailing - may Agni and Savitr release you from that sin!

If this daughter of yours has wailed with dishevelled hair in your house, doing evil through wailing (etc.).

If these young sisters have danced together in your house, doing evil through wailing (etc.). ${ }^{196}$

The word jāmi-, "sister", used for the young women (yuvatáyo) in v. 61, is of interest; when Viśvāvasu is implored, in the same hymn (v. 33 ), to leave the bride, he is told to "seek out a sister (jāmí-) who, [though] mature, dwells in her father's house; that is your share by birth - seek it out!" 197 But in the two following stanzas (34-5), he is instead implored to return to the apsarases, who are his "kin" (janitram; 35) and his "wives" (jāyá, 36$)$. The imprecation to leave the mortal woman to her husband and go to his own wives, the apsarases, occurs, as we have seen, elsewhere in AV. There thus seems to be a parallelism between the apsarases and the unmarried young women who are considered to belong to the gandharva(s). Vasilkov suggests that jammi- was the designation for those unmarried girls who belonged to the youth-societies.

There can be no doubt as to the fact that unmarried girls were considered "wives" of the gandharva(s); and, as we have seen, propitiatory offerings to Viśvāvasu or the gandharvas in general were performed either when the girl entered marriageable age, or before they were married off. The evidence for unmarried young men being

\footnotetext{
196 (Transl. partly following Whitney.) yádīmé kesíno jánā grhé te samánartișū ródena krnvaánto 'ghám/agnís țvā tásmād énasah savitấ ca prá muñcatām// yádīyám duhitấ táva vikeśy árudad grhé ródena krnvaty aghám/ agnís țvā tásmād énasah savitấ ca prá muñcatām// yáj jāmáyo yád yuvatáyo grhé te samánartișū ródena krnvatî́r aghám/agnis țvā tásmād énasah savitấ ca prá muñcatām//.

${ }^{197}$ jāmím icha pitrșádạn nyàktām sá te bhāgó janúșā tásya viddhi.
} 
connected to this kind of beings is sparser. Conceivably, the bamboostaff which is handed over to the snattaka-, the graduated Vedastudent, and which is addressed with the words, "Thou art the gandharva Viśvāvasu; protect thou me, guard thou me"198 (Jaimini Gṛhyasūtra 1.19; transl. Caland), may once have had some function cognate to the girl's offerings to the gandharva; the student, freed from his vow of celibacy (brahmacarya-) and entering the life of a married householder (grhastha-), is in a position similar to the girl who is about to marry, finding himself between two major life-stages. The gandharva's role as a being of transfer, responsible also for safely establishing the bride in her new home, may be of importance here too.

I would suggest, with some caution, that the single gandharva of old Vedic times filled the function of a tutelary deity of young boys and girls who had not yet entered the adult, settled life. This single gandharva seems to have lived on in the - generally conservative domestic ritual of the Grihyasuntras: it is to be noted that it is frequently the original gandharva, Viśvāvasu who appears in connection with the rites of passage preceding marriage or at the end of studentship; only occasionally is he given the qualifying epithet gandharvarāja-, as if to show why he, among all gandharvas, appears alone in this role.

Vasilkov has put forward the theory that the gandharvas and apsarases were seen as the celestial counterparts of the youths living together in a "men's house", known from many tribal societies, where they indulged in promiscuous relationships. The unmarried girls serving the young men as objects of their common enjoyment (an institution also known from ancient Iran) would correspond to the apsarases, who are indeed frequently described as celestial courtesans in the classical literature. My own interpretation, as given above, is slightly different, and attempts to pin down the "original" function of the single Vedic gandharva, as reflected not least in the later domestic ritual; but I think Vasilkov has collected enough evidence (to be discussed below) to establish a connection between the gandharvas and the "men's societies" of Vedic times. Conceivably, this is a later development; the single gandharva of the RV and parts of the AV is more likely to have been a tutelary deity of the pubescent youths, rather than identified with them. This is also the picture given by the

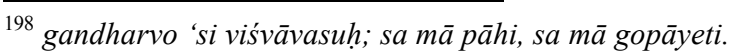


domestic rites. The exact relationship between the gandharva(s) and the "men's societies" is, however, difficult to decide on due to the scarce information we have on this kind of institution in ancient India. What can be ascertained is, first of all, that a "men's house" can be identified in the oft-mentioned sabhā- or "assembly hall"; ${ }^{199}$ second, that this sabha is fairly clearly put in connection with gandharvas, as well as prostitutes.

Before proceeding with a survey of Vasilkov's evidence, some words should be said on the nature of the Vedic sabhā. Well known from Vedic and epic literature to have been an exclusively male assembly hall with various functions - one of the most prominent being as a gambling hall - we have some very clear statements as to what kind of person used to frequent the sabhā. According to ŚB 13.1.9.8 and Taittirīya Brāhmaṇa 3.8.13.1, the sabhéya- or sabhā-goer is defined as a "young man" (sabheyo yuveti), who is in his first agespan (prathamavayasi $)$; "therefore [because he is a sabheya-], one who is in his first age-span is likely to become loved ${ }^{200}$ by women". ${ }^{201}$ The last statement is important in the light of what we know about the sexual activities in the sabhā, to which we will return later. The young age of the sabheya-, which is confirmed by some other texts, ${ }^{202}$ is of interest here; this holds especially for the term prathama- or pürvavayasin-. As Harry Falk has pointed out, ${ }^{203}$ the terms pürva-, madhya-, and uttama-vayasá- (the first, middle, and last age-spans) are used elsewhere in ŚB $(12.9 .1 .8 ; 12.2 .3 .4)$ to distinguish between three periods of a man's life: during the first of these, he still subsists on his father, though we may conclude from his frequenting the assembly hall and being attractive to women that he is considered an adult. Falk postulates that the term pürvavayasá- pertains to the years immediately following the end of studentship or brahmacarya-; as this used to last between ages 8 and 16, the pürvavayasá- would be the last years of adolescence, preceding the man's entering a settled life. This

\footnotetext{
${ }^{199}$ For the various meanings of Vedic sabhā-, see Rau 1957, pp. 75-81.

${ }^{200}$ For uses of the suffix - uka-, cf. Delbrück 2009, pp. 181-182.

${ }^{201}$ sabheyo yuveti eșa vai sabheyo yuvā yah prathamavayasi tasmātprathamavayasī strīnām priyo bhāvukah. The Taittirīya Brāhmaṇa-passage is identical, except for some slight variations.

${ }^{202}$ See Rau, pp. $77-8$.

${ }^{203}$ Falk 1986, pp. 93-4.
} 
seems, as Falk points out (and here he is followed by Oberlies ${ }^{204}$ ), to be the remnant of a very ancient system, closely paralleled in ancient Persia, ${ }^{205}$ where the student years occurred between ages 7 and 15, followed by the years (15-20) as a "young man", yuvān mart (cf. yuvan- as a synonym of sabheya-), then adulthood and lastly old age. Furthermore, the years following brahmacarya- also coincide with the young man's living as a vratacārin-, vrätya- or sattrin-, which terms, as Falk's study in particular has made clear, denote the member of a sort of Männerbund, subsisting on cattle-rustling while studying the "esoteric" parts of Vedic lore in the wilderness, and frequenting the $s a b h \bar{a}-$, where they indulged in (ritualistic) dicing, feasting, and promiscuous sexual relationships. This tallies more than well with Vasilkov's view of the sabhā- as a "men's house" for youngsters living in a Männerbund, though he doesn't seem to have taken notice of Falk's work on the topic.

Another important fact is that the sabheya-was always a male; "men go to the sabhä, not women" (MS 4.7.4 $4^{206}$ ). The only women allowed in the assembly hall were courtesans. ${ }^{207}$ According to Vādhūla Śrautasūtra 3.93, a woman who was "free to run off to the sabha" was called $s \bar{a} h \bar{a}-$, and was considered impure from the "heat of mating" (mithunasya ... śucā). That women who used to go to the sabha were not considered respectable is clear also from other texts (e.g., ŚB 1.3.1.21); most well-known, albeit late, is Mbh 2.62.8-9, where, in the context of the fateful game of dice in the sabha of the Kauravas, Draupadi is dragged into the assembly hall after having been staked and lost. There she complains, "What greater humiliation than that I, a woman of virtue and beauty, now must invade the sabhā ? ... From of old, we have heard, they do not bring law-minded (dharmyāhh) women into their hall." ${ }^{208}$ (Transl. van Buitenen, modified.) As protests are raised against her being forcedly led into the hall dressed in a single garment, Karna replies, "The Gods have

${ }^{204}$ Oberlies 1998, pp. 207ff; cf. 209 for a table showing the life-stages and their defining contents.

${ }^{205}$ The Iranian system was described by Widengren (1969, pp. 92-95), to whom Falk also refers.

${ }^{206}$ tásmāt púmāmsah sabhấm yánti ná stríyo.

${ }^{207}$ Falk, ibid. pp. $90 \mathrm{ff}$.

${ }^{208}$ kim tv ataḥ kṛpaṇam bhūyo yad aham strī satī śubhā/ sabhāmadhyam vigāhe 'dya ... // dharmyāh striyah sabhām pūrvam na nayantīti nạ śrutam/. 
laid down that a woman shall have one husband, scion of Kuru. She submits to many men and assuredly is a whore! Thus there is, I think, nothing strange about taking her into the hall, or to have her in one piece of clothing, or for that matter naked!" ${ }^{209}$ (2.61.35-6; transl. van Buitenen.) Here it appears that a prostitute (bandhakī) - which Draupadī is considered to be, due to her having five husbands - is fit to bring into the $s a b h \bar{a}$, and that her slight clothing is only proper in this regard; what follows after these words of Karna is the famous episode where the Kauravas attempt to strip Draupadī naked, to make her humiliation complete.

The people frequenting the sabh $\bar{a}$ were thus, at least in Vedic times, young men, and courtesans. In this connection, mention should be made of ŚB 13.4.3.7-8, where the gandharvas and apsarases are represented, at the horse sacrifice, by "beautiful young men" and "beautiful young women" (yuvānahlyuvatayah śobhanā). We have already seen that yuvan- earlier in the same book of ŚB is given as a synonym of sabheya-. Intriguing is also the commentary on Śānkhāyana Śrautasūtra 16.2.11 (being a quotation from the ŚB passage), where the apsarases' being represented by "beautiful young women" is explained with the words, "Because no other (women; anyāsām being feminine) enter the $s a b h \bar{a}^{, 210}$ (this being the scene of the sacrificial rite). The apsarases are thus, in the commentator's mind, defined by their being able to enter a $s a b h \bar{a}$; and this they have in common with the girls representing them at the ritual. The only reasonable explanation seems to be the view, prominent in the epic and classical literature, of the apsarases as celestial courtesans; a view which also seems to account, as Vasilkov suggests, for the presence of dancing and music-playing apsarases at the sabhās of gods like Indra or Brahmā, receiving the spirits of heroes slain in battle. ${ }^{211}$

The evidence provided by Vasilkov for a connection between gandharvas and the sabha is mainly based on materials from the epic,

${ }^{209}$ eko bhartā striyā devair vihitah kurunandana/ iyam tv anekavaśagā bandhakīti viniścitā// asyāh sabhām ānayanam na citram iti me matiḥ/ ekāmbaradharatvam vāpy atha vāpi vivastratā//.

${ }^{210}$ tasyaitāh (Eggeling's emend. tasyaitābhyah) sabhāyām anyāsām apraveśāt. Quoted by Eggeling, n. 2 on ŚB 13.4.3.8.

${ }^{211}$ Vasilkov p. 392. For the motif of the apsarases' receiving - and marrying - the dead heroes in paradise, like the Islamic houris (and, to some extent, the Nordic Valkyries), see Hara 2001. 
and thus late; but he also finds some support in Vedic texts. To begin with the epic part: Vasilkov notes a parallelism between the episode in the gambling hall in book 2, and the events at the court of Virāta in the beginning of book 4 . In the latter episode, the exiled Pandiava princes and their common wife live in disguise at the court of a foreign king; Draupadī, posing as a chambermaid, attempts to avert any sexual approaches by claiming to be the wife of five mighty, jealous gandharvas, but is nonetheless courted by the king's marshal, Kīcaka. When rejected, the enraged marshal chases her into the royal $s a b h \bar{a}$ and beats her up (4.15.6ff). After this, Draupadī invites him to a nightly meeting in the royal "dancing hall" (nartanāgāra-), where girls learn dancing by day, but which is empty at night - yet there is a large bed there. When Kicaka arrives in the dancing hall, he is met, not by Draupadī, but by Bhīma, the strongest of her husbands, who has been hiding in the bed; he kills Kîcaka by pushing his limbs into his trunk, a deed which Draupadī, when later questioned, attributes to her enraged gandharva husbands. Vasilkov suggests that the dancing hall, where erotic activity seems to take place at night, is to be compared to the "common dormitories" found in the young men's houses in many tribal societies; he also believes that the somewhat unusual term sairamahrī- used for Draupadī's profession at the court, while meaning "chambermaid" in later Sanskrit, should be understood as a euphemism for the similar-sounding word sādhāraṇi-, "common (to several men)". The wife of the five gandharvas would thus have been considered a prostitute, and her running away from Kīcaka into the sabhā, which she in book 2 considered it shameful for a woman to enter, would here be natural: "this time her appearance in the sabha created no scandal, evidently the $<<$ wife of the gandharvas $>>$ might enter the sabha without hindrance". ${ }^{212}$ This should be compared to the episode in book 2, where her forced presence in the sabha $\bar{a}$ is defended with reference to her five husbands; she is thus considered a harlot.

Vasilkov finds an intriguing parallel to these two episodes in the Aitareya Brāhmana, 1.27 - one version of the myth of the somabarter. As the gods hand over the goddess Vāc to the gandharvas, she is designated as mahānagnā-, a "stark-naked one". This rather rare term found in Vedic texts is used for some sort of prostitute, who figures in the context of a few rituals. One of the so-called Kuntāpa

${ }^{212}$ Ibid. p. 394. 
hymns (AV 20.136; RVKh 5.22), of highly obscene content and believed to have been employed in some fertility rite, depicts the mahānagnī in the act of cohabitation with a male counterpart, the mahānagna- (mentioned only here). Presumably, the ritual context may have been comparable to the copulation act forming part of the mahāvrata rite, where a prostitute (pumścalī-) had intercourse with a man from Magadha. ${ }^{213}$ In the $\mathrm{AiB}$ account, the mahānagnā goddess is clearly given away to the, plural, gandharvas as an object of their common sexual enjoyment; she is thus comparable to Draupadi in the dicing episode of Mbh 2, who is, first of all, married to several men; second, is called a "whore" for this reason; and lastly, is dragged halfdressed into the sabha, where the Kauravas then try to strip her entirely - make her "stark naked", like the mahānagnāa. Draupadī's posing as the wife of several gandharvas in book 4 makes the parallelism to AiB 1.27 even more striking. And in both episodes, a sabha - known to have been the scene of sexual activity between adolescent males and prostitutes - plays an important part. Vasilkov points out that there seems to be a connection between the mahanagna and unmarried young women in the wedding-hymns AV 14.1-2; in the first of these, there is a prayer (vs. 35-36) for the bride to be bestowed with the splendor (varcas-) of "the hind-parts of the mahanagna", as well as from liquor (sura $\bar{a}$-) and dice. The last two items are, as Vasilkov notes, prominent elements in the activity in the sabha (as a gambling hall and scene of feasting), ${ }^{214}$ and so are prostitutes. The blessing, he suggests, is meant to let the bride, who is leaving the adolescent life behind her, carry with her the best things of the sabha where she would previously have been among the girls serving the young men as concubines. ${ }^{215}$

A connection between gandharvas and the assembly hall is also pointed out in the episode of Arjuna's visit to Indra's heaven in book 3 , where the hero enters the god's sabhä, which is filled with singing,

${ }^{213}$ Cf. Hauer 1927, pp. 274-78; Rolland 1972, pp. 64-7.

${ }^{214}$ Ibid. p. 391; for surā- in the sabhä, cf. Falk 1986, pp. 89f.

${ }^{215}$ Vasilkov, p. 393, writes that, "in the next hymn ( $A V$. XIV.2) it is the apsarases who are asked to turn over to the bride their varcas", thus suggesting a parallelism between these beings and the mahānagnā. However, I have been unable to find such a prayer either in the hymn referred to or in the preceding one (14.1); at best, the gandharvas and apsarases are asked to be "good", not harmful, to the wedding procession, and Viśvāvasu is implored to return to his wives, the apsarases. 
music-playing and dancing gandharvas and apsarases. At Indra's behest, Arjuna is further given dancing lessons by the gandharva Citrasena. Noting that dancing is considered a manly sport in many societies - no doubt even in the rgvedic one, where we find warriorgods like Indra and the Maruts depicted as dancers - Vasilkov suggests that the Mbh tale reflects an initiation into the "men's house", where the adolescent boys were taught the skills and knowledge befitting an adult man. When Arjuna later rejects the sexual invitations of the apsaras Urvaśí, and is cursed by her to be deprived of his virility, this is interpreted as a failed sexual initiation; in the "men's house", the boys would learn about sex through relationships with courtesans; by not taking part in these, they would not attain real manhood, and would be considered like impotent. According to Vasilkov, the promiscuous relationships associated with the sabha would explain the concept of "gandharva marriages", which has been described above. He further suggests that the origin of classical Skt. ganik $\bar{a}-$, "courtesan", is to be sought in the ganas ("hosts"), which is the common term by which the ancient sodalities or Männerbünde were referred to in Vedic and later literature; ${ }^{216} \mathrm{a}$

\footnotetext{
216 "The word gana is used in the Vedas mostly for the host of the Maruts, the young warriors $<<$ of the same age $>>$, $<<$ grown up together $>>-$ which clearly shows them to be the representation of an age-group. They possess collectively a young girl (goddess Rodasī) as sādhārañi (the term means $<<\mathrm{a}$ woman in common possession $>>$ ). In postVedic mythology the ganas became the wild and furious spirits, the host of RudraSiva. But at the same time historical sources speak of ganas as of some real militarypolitical organisations (interpreted by most scholars as $<<$ kșatriya republics $>>$ or $<<$ oligarchies $>>$ ). Surprisingly, here again we find in the texts assertions that some of these $<<$ historical $>>$ ganas did not know the institution of marriage." (Vasilkov pp. 396-397.) On the term gana, see further Bollée 1981, Falk pp. 104-107. That the ganas of the early Vedic Maruts are mythological projections of the sodalities is accepted by both these scholars; indeed, there is a probable etymological relationship between marut- and these gods' common designation márya-, "young man, warrior" (see below), from which word seems also to be derived malla-, the name of a warlike "tribe" with a non-monarchical administration and a practice of sharing each-others' slave-girls for sexual purposes (Bollée, op.cit.). - Oberlies notes (1998, p. 229 n. 386) that the recognition of gandharvas as a sort of celestial vrātyas raises questions as to the relationship between these beings and the Maruts. I do not have an answer to this; conceivably, they could represent different age-grades (the gandharvas certainly appear more boyish and carefree than the warlike Maruts), or, as I suspect, the gandharvas' connection to adolescents might be a late development (no traces seem to be find in the oldest Veda). In such a case, they may have taken over the role of the increasingly obsolete Maruts.
} 
ganik $\bar{a}$ would, then, originally have been a woman "belonging to the gana", as a common sexual partner shared by the unmarried young men.

While not suggesting that each and every trait in the conception of gandharvas and apsarases can be explained with reference to their connection with adolescence and the "men's house", I do believe such a connection to be well established, and a likely explanation for some of these traits. This holds for the frequent association between apsarases and dicing (this being one of the most prominent activities in the $s a b h \bar{a}$ ); some similar association on the part of the gandharvas might possibly be implied in the name of the "Kali gandharvas" (AV 10.10.13; JB 1.154-55). ${ }^{217}$ As (decent) women were barred from the gambling hall, it seems remarkable that the female apsarases are to be found there, presiding over the dicing. Considering the traditional conception of these deities as celestial courtesans, however, this fact becomes less remarkable. Promiscuous sexual activity was most certainly an established part of life in the sabha $;{ }^{218}$ and so were amusements such as dancing, feasting, and drinking. Telling is the association of the sabha with the rare words narist $t(h) \bar{a}$ - and narmá- in AV 7.12.2 and VS 30.6. The former passage - occurring in an invocation of the sabha and the samiti- ("assembly") - runs, "We know your name, O Sabhā - Nariștā is your name!" "219 A hint of what narișt $\bar{a}$ - might be is provided by AV 11.8.24, where the word appears among a number of feelings and activities entering Man upon his creation by the gods: various forms of joy and pleasure (ānandá módāh pramúdo 'bhīmodamúdaś), laughter (hasó), and dance (nrttäni). The word was rendered as "sport" by Whitney, "mirth" by Bloomfield. In VS 30.6, TB 3.4.1.2 (dealing with the human sacrifice, where various deities and abstract powers are assigned victims with different professions), it appears again together with the same or similar terms: "To Dance, a bard (sūta-); to Song, an actor (? śailūṣa-

\footnotetext{
${ }^{217}$ The name would thus be connected with káli-, the losing throw in the dice game (and the demon of gambling in the epic). The accent is not the same; yet the connection has been considered by Mayrhofer and others (see Mayrhofer s.v. kali-, with references).

${ }^{218}$ Falk, pp. $90 \mathrm{ff}$.

${ }^{219}$ vidmá te sabhe náma narișțā nắma vă asi.
} 
${ }^{220}$ ); to Dharma, a sabhā-goer; to Narișthā, a formidable one (bhīmala); to Narma, a panegyrist (rebha-); to Laughter, an artisan; to Sexual Pleasure (ānanda-), a womanizer; to Joy, a bastard; to Intelligence, a chariot-maker; to Firmness, a carpenter." ${ }^{221}$ In VS 30.20, on the other hand, narma- is assigned a harlot (pumścalū-).

The mention of a sabhäcara- in the list is certainly interesting; his association with the seemingly out-of-place deity Dharma is to be attributed to the assembly hall's well-known function as a court of justice. ${ }^{222}$ The words nariștha recognized, to be derived from the same root and would have similar meanings; the latter is probably not to be separated from classical Skt. narman-, "joke". The same root $n r-$ or nar- appears in rgvedic nrtí-, which also occurs next to hása- "laughter" in RV 10.18.3. ${ }^{223} \mathrm{~A}$ suggested correspondence between the root $n r$ - and $n r t$ - "to dance" is now commonly rejected, ${ }^{224}$ and Kuiper has instead suggested a meaning "to be manly", and approximate translations of the two derivative words as "manifestation of strength" or "manifestation of one's social prestige". This "manifestation" could take the form of dance (as said, a most manly sport in many societies), festivities, and sports in the ritualized milieu of the sabhä; the assigning of a bhimala - to the abstract Narișthā points to the prestige placed in the mastering of such activities. Kuiper stresses the ritualistic, contest nature of these activities - the sabha also being the scene of (ritualistic) dice games and verbal contests - and is no doubt right that we shouldn't take "dance" etc. as mere forms of frolicking around, though he may arguably be downplaying the amusement aspect a bit. In any case, the association of the sabh $\bar{a}$ with words denoting a manifestation of manly strength is certainly fitting for a "men's house", where the young boys learnt the "manly" arts and sports.

It is now largely accepted that age-group societies consisting of young men - a form of Männerbünde - existed in Proto-Indo-Iranian

\footnotetext{
${ }^{220}$ The meaning of the word in Vedic times is not certain. Note that Śailūṣa appears as the name of a gandharva prince in the epics (Böhtlingk \& Roth, s.v.).

221 nrttấya sūtám gītấya śailūṣám dhármāya sabhācarám naríṣthāyai bhīmalám narmằya rebhám hásāya káàim ānandáya strīṣukhám pramáde kumārīputrám medhăyai rathakārám dháiryāya tákșānam. I must admit that I don't know what the last two "deities" and their victims are doing in this enumeration.

${ }^{222}$ Rau, pp. 80-81.

${ }^{223}$ Kuiper 1960, p. 275

${ }^{224}$ Ibid.; Mayrhofer 1986, s.v. narmá-.
} 
times, and that their members were designated as *marya-, lit. "young man", secondarily "warrior". They seem to have been bellicose groups subsisting on raids and cattle-rustling. The word márya- fell into disuse in post-rgvedic times, but it now seems established through studies like those of Bollée (1981) and Falk (1986) that the "sodalities" (Bollée) lived on throughout the Vedic period, and probably longer. The most likely candidates when we look for inheritors of the máryas, are undoubtedly the vrätyas or "vow-takers". Long believed to have belonged outside the boundaries of Vedic culture proper, being associated with rites and customs considered impure by the authors of the sacrificial texts, the vrātyas are now ${ }^{225}$ considered to have formed an important part of a Vedic age-group system; according to Falk, they were Veda-students who had completed their brahmacarya- and now spent a few years in sodalities, living in the wilderness (aranya-) and studying the "esoteric" parts (äranyaka-, the "wilderness-lore") of the sacred knowledge while subsisting on raiding neighbouring territories. (This lore included, i.a., the sattra and pravargya rites.) They were certainly closely associated with the sabha (which was located in the wilderness, outside the village boundaries) and the ritualistic dicegame that took place there; ${ }^{226}$ as well as to courtesans - those women who were allowed in the sabhā, first of all, but also - through the mahāvrata ritual - to the pumiścalī- or harlot (cf. AV 15.2) who performed an obscene dialogue with a brahmacārin, followed by ritualistic intercourse with a man from Magadha. Now, it is certainly interesting to find the gandharvas and apsarases, in the context of the human sacrifice, being assigned - a vrātya (VS 30.8, TB 3.4.5.5). Though such a direct connection is, to my knowledge, limited to this passage, the (as I think, well established) association of the gandharvas with adolescence and the sabha makes it difficult to reject it as simply ad hoc. That men's societies across the globe have been posing as representatives or embodiments of spirits or ancestors is well-known from ethnography, and this appears to have been the case also among several Indo-European peoples. ${ }^{227}$

\footnotetext{
${ }^{225}$ Heesterman 1962; Falk 1986.

${ }^{226}$ This is the main subject of Falk's study.

${ }^{227}$ See Kershaw 2000 for a survey of old and newer studies; cf. also Oberlies 1998, pp. $206 \mathrm{ff}$.
} 
It may be noted in this regard that there is some kind of connection, pointed out by several scholars, ${ }^{228}$ between gandharvas and the sage Keśin (or Baka) Dārbhya, likely to be identical with the "shaman" Keśin ("the long-haired one") of RV 10.136, who travels "along the course of the apsarases and gandharvas and the wild animals". This Keśin Dārbhya also has clear affinities to the vrātyas and the (with them closely associated ${ }^{229}$ ) sattra sacrifice, ${ }^{230}$ which he, for instance, teaches to the gandharvas and apsarases in MS 1.4.12, and which is in AVP 2.52.1 said to have been instituted by "the keśins". Indeed, the last verses of the vrätyastoma are called keśinin according to JB 2.226, which is explained by the fact that vrātyas "keep themselves with long hair" (keśair iva hy ete caranti). ${ }^{231}$ Elsewhere, Keśin has a group of followers called keśinīh (ŚB 11.8.4.6) or kaiśinīh (Vādhūla Śrautasūtra 4.37); and in older times these appear to have been called simply by the plural keśinah, "keśins". 232 As Falk and others have noted, ${ }^{233}$ long hair is a very common characteristic of young males in age-group societies, ${ }^{234}$ and both brahmacārins and vrātyas let their hair and beards grow long. Long hair is also typical for the gandharvas, who, as we have seen,

\footnotetext{
${ }^{228}$ Koskikallio 1995; Deeg 1993, pp. 107, 114-115. In JB 3.312, Keśin Dārbhya’s teacher is mentioned as Kabandha Âtharvana; this is precisely the name by which the woman-possessing gandharva of $B \bar{A} U$ 3.7.1 presents himself, suggesting that Kabandha is dead but has returned as a gandharva. In Baudhāyana Śrautasūtra 18.26, Keśin and his band of sattrins are associated with a priest named Gandharvāyana Vāleya Āgniveśya, who puts a curse on a rivalling band of vrātyas.

229 "In der ältesten uns faßbaren Zeit gab es kein Sattra ohne nachfolgenden Auszug (vrātyā) und keine Vrātyas, die nicht als Sattrins begonnen hätten ... Sattra-Opfer und Vrātya-Wesen trennten sich zur Brāhmaṇa-Zeit und durchliefen eigene Entwicklungen.” (Falk 1986, pp. 30-31.) According to Falk, the distribution of booty from their raids took place at the sattras.

${ }^{230}$ Heesterman 1962, p. 16; Falk 1986, pp. 18, 40, 55, 59, 69; Koskikallio 1995.

${ }^{231}$ Less likely "go about with (long) hair" (Heesterman, ibid.); for the use of car- with the instrumental, cf. Delbrück, pp. 134-5.

${ }^{232}$ This plural still appears in KS 30.2 (which talks about "the keśins of Dārbhya") and ŚB 11.8.4.1, as has been pointed out by Deeg (p. 107), who, however, does not relate this usage to the keśinīh.

${ }^{233}$ Falk pp. 18, 69ff; Bollée 1981, p. 174; for long-haired vrātyas cf. also Heesterman 1962.

${ }^{234}$ For instance, in ancient Iran, whose societies of young warriors were probably historically related to those of India; cf. Widengren 1969, pp. 19, 34-37.
} 
had their hair arranged into plaits. ${ }^{235}$ In this connection, a passage from the Jain Suyyagadamga Sutta (1.7.10) is certainly interesting; as it happens, I came upon it only after finishing the above discussion. I quote here from Jacobi's translation:

Men die as embryos, or as babies who do not yet talk, or who do so already; other men, as boys wearing five tufts of hair (pamcasihä, Skt. pañcasikha-), or as youths, or in the middle age; at the expiration of their life all leave the body and die. ${ }^{236}$ (Jacobi 2004 [1895].)

Pañcaśikha is, as we have seen, the name of a prominent gandharva (cf. already the sikhandin- of AV), and wearing five plaits is a characteristic also ascribed to apsarases. ${ }^{237}$ In the passage quoted, pañcaśikha- clearly designates an adolescent boy; the commentator Sílānika glosses it as kumāra-, "boy, youngling". A similar hairstyle seems to have been customary among the ancient Tamils, though in this case, amongst girls: "Many girls had their hair done into five plaits. After marriage the plaits gave place to a coiffure, known commonly as 'Kondai'.,238

\section{Concluding remarks}

There are some further features of the gandharva mythology which are reminiscent of activities connected with the vrātyas - for example, the mahāvrata- or New Year festival, which is associated with them, ${ }^{239}$ features music (e.g., from the lute or vin̄a) , dance, ritualistic swinging, and cohabitation with a prostitute. ${ }^{240}$ But a mere enumeration of common characteristics would be futile. What I think can be reasonably well established is a connection between gandharvas and the non-settled life of young males, characterized by activities such as

\footnotetext{
${ }^{235}$ Possibly, already their designation in RV 3.38.6 as "wind-haired" (vāyúkeśa-) i.e., with windblown hair? - points to this conception.

${ }^{236}$ gabbhāi mijjaṃti buyā- 'buyāṇā ṇarā pare pamcasihā kumārāa juvāṇagā majjhima theragā ya cayaminti te âukhae palīnăl/.

${ }^{237}$ See above, n. 109.

${ }^{238}$ Pillay 1975, p. 303 (cf. 341). Similarly, Vasilkov (p. 394 n.) refers, in connection with the apsarases, to "the custom of Tamil girls to wear five plaits during the season of their love-play with boys in the rice-fields"; the study (in Russian) to which he refers was not accessible to me.

${ }^{239}$ As made clear by Hauer 1927, chap. II: "Die Vrātya und das Mahāvrata".

${ }^{240}$ Clearly a sort of vegetation magic.
} 
dancing and feasting, and some which are frequently connected with the sabhā: most notably promiscuity and dicing. As the celibate Vedastudent would be unlikely to engage in such activities, the sabhāattending youth, yuvān, who has completed his brahmacarya- but has not yet married and settled down, is the most likely candidate when we look for an earthly "counterpart" of the gandharvas (as the yuvānah indeed are in ŚB 13.4.3.7). As the vrātyas clearly constituted at least a branch of this age-group, their association with gandharvas, though occasional, seems to be accounted for. As this was also the age when the esoteric parts of Vedic lore were studied in the wilderness, and sacrifices like the sattra-were performed, it would be tempting to connect this with the gandharvas' well-known knowledge of sacred mysteries (and especially rituals).

Summing up the results of this study, it has to be admitted that it is hard to find a single dominating trait that could explain the formation of the mythological being under discussion. The gandharva appears as a mediator (of knowledge, etc.) between heaven and earth; as guardian of the soma in heaven; as a mischievous spirit possessing women and causing insanity and miscarriages; as a fertility deity, etc. An attempt has, however, been made to show that many of these various traits and functions are interconnected; thus, the conception of the gandharva as beautiful, lusty and pleasure-seeking would be befitting a spirit of generation, while at the same time being closely connected with his possessing mortal women. At the basis of the Middle and Late Vedic mythology around gandharvas, it has been argued, is the exchange of sacral knowledge and substances for profane, especially sexual, enjoyment; this exchange takes on the one hand the form of possession of women, on the other, it is enacted in myths such as that of the soma-barter. A similar "intermediary" function of the gandharva, as noticed especially by Oberlies, could arguably explain a fair deal of the myths and rituals involving this kind of being: the transfer of soma to earth, of divine secrets to mortals, of pubescent girls to the married life. It may certainly be responsible for the gandharva's connection with rites of passage, such as weddings, and his being a sort of guardian deity of pre-married girls and, it seems, boys. Himself of youthful appearance and character, he appears to be especially connected with the "first" or adolescent life-stage (following childhood and studies, and thus a sort of "intermediary" stage before marriage and a settled life). This would 
also explain the gandharvas' and apsarases' association with the $s a b h \bar{a}$, with dice, with vrātyas and with prostitutes.

All this being said, it should be clearly stated that the subject is in need of deeper study; as is the entire, rather loose and confusing mythology around gandharvas and apsarases and its development through the ages. Hopefully, the present attempt will be a step in this direction.

\section{Abbreviations and bibliography}

Aarne, Antti, and Stith Thompson, 1981 [1951]. The Types of the Folktale. Helsinki: Suomalainen Tiedeakatemia.

$\mathrm{AiB}=$ Aitareya Brāhmaṇa. Ed. Theodor Aufrecht, Bonn: Adolph Marcus, 1879.

Āpastamba Gṛhyasūtra: Apastamba-grhyasūtra, with the commentaries the Anākula of Haradatta Miśra and the Tātparyadarśana of Sudarśanācārya. Ed. Umesh Chandra Pandey, Benares: Jai Krishnadas-Haridas Gupta, 1928.

AV: Atharvaveda (Śaunaka). See Joshi 2004.

AVP: Atharvaveda (Paippalāda). Atharva Veda of the Paippalādas, ed. Raghu Vira, 3 vols. (1936, 1940, 1942). Lahore: International Academy of Indian Culture.

Barnett, L.D., 1928. "Yama, Gandharva, and Glaucus." Bulletin of the School of Oriental and African Studies Vol. 4, No. 4, pp. 70316.

BĀU: Bṛhadāraṇyaka Upaniṣad. See Olivelle 1998.

BGS: Baudhāyana Grrhyasūtra: Bodhāyanagrhyasūtram of Bodhāyana Maharși, ed. L. Srinivasachar and R. S. Sastri, Mysore: Oriental Research Institute, 1983.

Bhattacharyya, N. N., 2000. Indian Demonology: The Inverted Pantheon. Delhi: Munshiram Manoharlal.

Bloomfield, Maurice (transl.), 1897. Hymns of the Atharva Veda. Oxford: Clarendon Press. 
, 1906. A Vedic Concordance. Cambridge, Mass.: Harvard University Press.

Bodewitz, Henk. W. (trans1.), 1990. The Jyotiștoma Ritual: Jaiminīya Brāhmana I, 66-364. Leiden: Brill.

Böhtlingk, Otto, and Rudolph Roth, 1855-75. Sanskrit-Wörterbuch. 17. St. Petersburg: Kaiserliche Akademie der Wissenschaften.

Bollée, Willem B., 1981. "The Indo-European Sodalities in Ancient India." Zeitschrift der Deutschen Morgenländischen Gesellschaft 131, pp. 172-91.

Caland, Willem, 1928. "Eine vierte Mitteilung über das Vādhūlasūtra." Acta Orientalia 6, pp. 97-241. 11.

(trans1.), 1931. Pañcavimśa-Brāhmana: The Brāhmana of Twenty Five Chapters. Calcutta: Baptist Mission Press.

__ , 1970 [1919]. Das Jaiminīya-Brāhmaṇa in Auswahl. Wiesbaden: Dr. Martin Sändig.

Chalmers, Lord Robert (transl.), 1926. Further Dialogues of the Buddha. Vol. 1. London: Oxford University Press.

Connor, W. R., 1988. "Seized by the Nymphs: Nympholepsy and Symbolic Expression in Classical Greece." Classical Antiquity 1, pp. 155-89.

Deeg, Max, 1993. "Shamanism in the Veda: The Keśin-Hymn (10.136), the Journey to Heaven of Vasiștha (RV. 7.88) and the Mahāvrata-Ritual." Nagoya Studies in Indian Culture and Buddhism: Sambhāṣā 14, pp. 96-144.

Delbrück, Berthold, 2009 [1888]. Altindische Syntax. New York: Cambridge University Press.

Eggeling, Julius (transl.), 1882. The Satapatha-Brâhmana According to the Text of the Mâdhyandina School. 1-5. Oxford: Clarendon Press.

Falk, Harry, 1986. Bruderschaft und Würfelspiel. Freiburg: Hedwig Falk. 
Geldner, Karl F., 1951. Der Rig-Veda: Aus dem Sanskrit ins Deutsche übersetzt. 1-3. Cambridge, Massachusetts: Harvard University Press.

Gonda, Jan, 1963. The Vision of the Vedic Poets. The Hague: Mouton $\&$ co.

, 1975. "A Note on the Vedic Student's Staff." Selected Studies 4, Leiden: Brill, pp. 160-70.

, 1980. Vedic Ritual: The Non-Solemn Rites. Leiden: Brill.

Gotō, Toshifumi, 2000. "Purūravas und Urvaśī aus dem neuentdeckten Vādhūla-Anvākhyāna (Ed. Ikari).” In Anusantatyai. Festschrift für Johanna Narten, eds. A. Hintze and E. Tichy, Dettelbach: Röll, pp. 79-110.

Grassmann, Hermann, 1999 [1873]. Wörterbuch zum Rig-Veda. Delhi: Motilal Banarsidass.

Haas, Cornelia, 2004. Wie man den Veda lesen kann. Gandharva und die $>>$ Zwischenzustände $<<$ im Rgveda und im Kommentar des Sāyaṇa - Wege der Interpretation eines archaischen Textes. Göttingen: Vandenhoeck \& Ruprecht.

Hara, Minoru, 2001. “Apsaras and Hero.” Journal of Indian Philosophy 29, pp. 135-53.

Hauer, J. W., 1927. Der Vrātya. Untersuchungen über die nichtbrahmanische Religion Altindiens. I. Stuttgart: Verlag von W. Kohlhammer.

Heesterman, J. C., 1962. "Vrātya and Sacrifice.” Indo-Iranian Journal 6 , pp. $1-37$.

Hillebrandt, Alfred, 1987. "Die Bedeutung von Gandharva." Kleine Schriften, ed. Rahul Peter Das, Stuttgart: Franz Seiner Verlag, pp. 179-86. [Originally appearing in Sitzungen der orientalischsprachwissenschaftlichen Sektion, 1906.]

, 1999. Vedic Mythology. 1-2. Transl. S. R. Sarma. Delhi: Motilal Banarsidass.

Hoffmann, Karl, 1960. "Textkritisches zum Jaiminīya-Brāhmaṇa." Indo-Iranian Journal 4, pp. 1-36. [Repr. in Aufsätze zur 
Indoiranistik I, ed. J. Narten, Wiesbaden: Reichert, 1975, pp. 77-112.]

Hopkins, Edward Washburn, 1915. Epic Mythology. Strassburg: Karl J. Trübner.

Jacobi, Hermann, 2004 [1895]. Jaina Sūtras II. Delhi: Motilal Banarsidass. (Sacred Books of the East vols. 22, 45.)

Jaimini Gṛhyasūtra. Ed. and transl. Willem Caland. Delhi: Motilal Banarsidass, 1984 [1922].

JB: Jaiminīya Brāhmaṇa of the Sāmaveda. Ed. Raghu Vira and Lokesh Chandra. Delhi: Motilal Banarsidass, 1986 [1954].

Jamison, Stephanie W., 2008. Review of Haas 2004. Journal of the American Oriental Society Vol. 128, No. 2, pp. 394-95.

Jamison, Stephanie W., and Joel P. Brereton (transl.), 2014. The Rigveda: The Earliest Religious Poetry of India. 3 vols. New York: Oxford University Press.

Joshi, J. R., 1977. Some Minor Divinities in Vedic Mythology and Ritual. Pune: Deccan College Postgraduate and Research Institute.

Joshi, K. L. (ed.), 2004. Atharvaveda Samhitā: Sanskrit Text, English Translation, Notes \& Index of Verses. English Translation according to W.D. Whitney and Bhāsya of Sāyanāāārya. Delhi: Parimal Publications.

Kane, P. V., 1974. History of Dharmaśāstra. Vol. 2.1-2. Poona: Bhandarkar Oriental Research Institute.

Kaușìtaka Grhyasūtras. With the Commentary of Bhavatrāta. Ed. T. R. Chintamani. New Delhi: Meharchand Lachhmandas Publications, 2004 [1944].

Keith, Arthur Berriedale (transl.), 1914. The Veda of the Black Yajus School entitled Taittiriya Sanhita. 2 vols. Cambridge, Massachusetts: Harvard University Press.

(transl.), 1976 [1920]. Rigveda Brahmanas. New York: Gordon Press. 
_ 2007 [1925]. The Religion and Philosophy of the Veda and Upanishads. Delhi: Motilal Banarsidass.

Keller, Mary, 2002. The Hammer and the Flute: Women, Power \& Spirit Possession. Baltimore: Johns Hopkins University Press.

Kershaw, Kris, 2000. The One-eyed God: Odin and the (Indo-) Germanic Männerbünde. Washington D.C.: Institute for the Study of Man.

KGS: The Käthakagrhyasūtra with Extracts from Three Commentaries, an Appendix and Indices. Ed. Willem Caland. Lahore: D.A.V. College.

Koskikallio, Petteri, 1995. "Baka Dālbhya: A Complex Character in Vedic Ritual Texts, Epics and Purāṇas.” Electronic Journal of Vedic Studies Vol. 1, No. 3.

Kuiper, F. B. J., 1960. "The Ancient Aryan Verbal Contest.” IndoIranian Journal 4, pp. 217-84. , 1979. Varuña and Vidūṣaka: On the Origin of the Sanskrit Drama. Amsterdam: North-Holland Publishing Company.

__ , 1996. "Gandharva and Soma." Studien zur Indologie und Iranistik 20, pp. 225-55.

Langer, Rita, 2000. Das Bewusstsein als Träger des Lebens. Einige weniger beachtete Aspekte des viñ̃ānna im Pālikanon. Vienna: Arbeitskreis für tibetische und buddhistische Studien Universität Wien.

Lévi, Sylvain, 1898. La doctrine du sacrifice dans les Brahmanas. Paris: Ernest Leroux.

Lewis, I. M., 1975. Ecstatic Religion: An Anthropological Study of Spirit Possession and Shamanism. Harmondsworth: Penguin.

Lüders, Heinrich, 1951-59. Varuṇa. 2 vols. Ed. L. Alsdorf. Göttingen: Vandenhoeck \& Ruprecht.

Ludvik, Catherine, 1998. "The Barter for Soma. Vāc, women's love of music, and Sarasvatī's vīnă." AION Vol. 58, No. 3-4, pp. 34758. 
Macdonell, Arthur A., 1897. Vedic Mythology. Strassburg: Verlag von Karl J. Trübner.

Mannhardt, Wilhelm, 1875. Wald- und Feldkulte. Vol. 1. Berlin: Gebrüder Borntraeger.

Mayrhofer, Manfred, 1986. Etymologisches Wörterbuch des Altindoarischen. Heidelberg: Carl Winter Universitätsverlag.

Mbh: Mahābhārata. 19 vols. Eds. V.S. Sukthankar et al. Poona: Bhandarkar Oriental Research Institute, 1927-66.

The Milindapañho. Ed. V. Trenckner. London: Pali Text Society, 1880.

MN: Majjhima Nikāya. 3 vols. Ed. R. Chalmers and V. Trenckner. London: Pali Text Society, 1898.

MS: Yajurvedīya Maitrāyaṇi-Saṃhitā, ed. S. D. Satavalekar. Paradi: Svadhyaya Mandala, vikramīyasaṃvat 1998 (= 1942?).

Oberlies, Thomas, 1998. Die Religion des Rgveda. I. Vienna: Institut für Indologie der Universität Wien.

__ 2005. "Der Gandharva und die drei Tage währende 'Quarantäne'”. Indo-Iranian Journal 48, pp. 97-109.

__ 2009. "Gandharvas and Apsarases." In Brill's Encyclopedia of Hinduism, Leiden: Brill (electronic version).

__ 2012. Der Rigveda und seine Religion. Berlin: Verlag der Weltreligionen.

Oertel, Hanns, 1896. "The Jāiminīya or Talavakāra Upaniṣad Brāhmaṇa." Journal of the American Oriental Society 16, pp. 79-260.

O'Flaherty, Wendy Doniger, 1985. Tales of Sex and Violence: Folklore, Sacrifice, and Danger in the Jaiminīya Brāhmaṇa. Chicago: University of Chicago Press.

Oldenberg, Hermann (transl.), 1886. The Grihya Sūtras. 1-2. Oxford: Clarendon Press.

_ 1894. Die Religion des Veda. Berlin: Verlag von Wilhelm Hertz. 
Olivelle, Patrick, 1998. The Early Upanișads: Annotated Text and Translation. New York: Oxford University Press.

Pandey, Rajbali, 2002 [1969]. Hindu Samskāras: Socio-Religious Study of the Hindu Sacraments. Delhi: Motilal Banarsidass.

Parpola, Asko, 2015. The Roots of Hinduism: The Early Aryans and the Indus Civlization. New York: Oxford University Press.

PB = Pañcavimiśa Brāhmaṇa: Tāṇdyamahābrāhmaṇa, 1-2, ed. A. C. Śāstri and P. Śāstri, Benares: Kāśi Sanskrit Series, 1935-36.

Pillay, K. K., 1975 [1969]. A Social History of the Tamils. Vol. 1. University of Madras.

Pischel, Richard, and Karl F. Geldner, 1889. Vedische Studien. Vol. 1. Stuttgart: Verlag von W. Kohlhammer.

Rau, Wilhelm, 1957. Staat und Gesellschaft im Alten Indien. Wiesbaden: Otto Harassowitz.

Rhys Davids, T. W. (transl.), 1899. Dialogues of the Buddha. 1-3. London: Oxford University Press.

Rhys Davids, T. W., and William Stede, 1952 [1921]. The Pali Text Society's Pali-English Dictionary. London: The Pali Text Society.

Rolland, Pierre, 1972. Le Mahāvrata. Contribution à l'étude d'un rituel solennel védique. Göttingen: Vandenhoeck \& Ruprecht.

RV: Rig Veda: A Metrically Restored Text. Ed. B. van Nooten and G. Holland. Cambridge, Mass.: Harvard University Press, 1994.

RVKh.: R.gveda-Khilāni. See Scheftelowitz 1966 [1906].

Ṣaḍvimśsa Brāhmaṇa: Șaḍvinsśa Brāhmana with Vedārthaprakāśa of Säyana. Ed. Bellikoth Ramachandra Sharma. Tirupati: Kendriya Sanskrit Vidyapeetha, 1967.

Sāmavidhāna Brāhmaṇa. Ed. A. C. Burnell. London: Trübner \& Co, 1873.

Śānkhāyana Gṛhyasūtra. Ed. Hermann Oldenberg, Indische Studien 15,1878 , pp. 1-166. 
ŚB: Śatapatha Brāhmaṇa (Mādhyandina). Ed. Albrecht Weber. Varanasi: Chowkhamba Sanskrit Series No. 96, 1964.

Scheftelowitz, Isidor, 1966 [1906]. Die Apokryphen des Rgveda. Darmstadt: Georg Olms Verlagsbuchhandlung.

Schmidt, Bettina E., and Lucy Huskinson (eds.), 2010. Spirit Possession and Trance: New Interdisciplinary Perspectives. London \& New York: Continuum.

Schneider, Ulrich, 1967. "Yama und Yamī (RVX 10)", Indo-Iranian Journal 10, pp. 1-32.

Sered, Susan Starr, 1994. "Summoning the Spirits." Chap. 9 in Priestess, Mother, Sacred Sister: Religions Dominated by Women, New York: Oxford University Press.

Slaje, Walter, 1997. "Zur Erklärung der sog. 'Tobiasnächte' im vedischen Indien." Studien zur Indologie und Iranistik 21, pp. 207-34.

Smith, Frederick M., 2009. Deity and Spirit Possession in South Asia. Delhi: Motilal Banarsidass.

Sūyagaḍaṃgasuttaṃ. Ed. Muni Jambūvijaya. Bombay: Shrī Mahāvīra Jaina Vidyālaya, 1978.

Taittirīya Āranyaka. Edited with the commentary of Sāyaṇa by Rājendralāla Mitra. Calcutta: Asiatic Society of Bengal, 1872.

Thite, G. U., 1987. "Gandharvas and Apsarasas in the Veda." Journal of the Indian Musicological Society Vol. 18, No. 2, pp. 52-63.

TS: Taittirīya Saṃhitā. Ed. Albrecht Weber, Indische Studien 11-12, Leipzig: Brockhaus, 1871-72.

van Buitenen, J. A. B. (trans1.), 1975. The Mahābhārata: 2. The Book of the Assembly Hall. 3. The Book of the Forest. Chicago: University of Chicago Press.

- (transl.), 1978. The Mahābhārata: 4. The Book of Virāta. 5. The Book of the Effort. Chicago: University of Chicago Press.

Vasilkov, Yaroslav V., 1990. "Draupadī in the Assembly-Hall, Gandharva-Husbands, and the Origin of the Ganikās." Indologica Taurinensia 16, pp. 387-98. 
VS: Vājasaneyi-Mādhyandina-Śukla-Yajurveda-Samhitā. Ed. with the commentaries of Uvața and Mahīdhara by Jagadīśa Lāl Śāstri. Delhi: Motilal Banarsidass, 1999 [1971].

Wayman, Alex, 2002. "The Intermediate-state Dispute in Buddhism." Buddhist Insight: Essays by Alex Wayman, Delhi: Motilal Banarsidass, pp. 251-68. [Originally published in Buddhist Studies in Honour of I. B. Horner, Dordrecht: D. Reidel, 1974, pp. 227-37.]

West, Martin L., 2007. Indo-European Poetry and Myth. New York: Oxford University Press.

Wijesekera, O. H. de A., 1994a. "Vedic Gandharva and Pali Gandhabba." Buddhist and Vedic Studies: A Miscellany. Delhi: Motilal Banarsidass, pp. 175-212. [Originally published in University of Ceylon Review 3, 1945, pp. 73-107.]

, 1994b: "The Concept of Viññāṇa in Theravāda Buddhism." Buddhist and Vedic Studies: A Miscellany. Delhi: Motilal Banarsidass, pp. 103-112. [Originally published in Journal of the American Oriental Society Vol. 84, No. 3 1964, pp. 254259.]

Windisch, Ernst, 1908. Buddha's Geburt und die Lehre von der Seelenwanderung. Leipzig: B. G. Teubner.

Winternitz, Moritz, 1895. "Nejamesha, Naigamesha, Nemeso." Journal of the Royal Asiatic Society 27, pp. 149-55.

Witzel, Michael, 1987. "The Case of the Shattered Head." Studien zur Indologie und Iranistik 13-14, pp. 363-415.

_ 2003: "Linguistic Evidence for Cultural Exchange in Prehistoric Western Central Asia." Sino-Platonic Papers 129, pp. 1-70.

, 2004. "The Rgvedic Religious System." In Arlo Griffiths and Jan E.M. Houben (eds.), The Vedas: Texts, Language \& Ritual, Gröningen: Egbert Forsten, pp. 581-636.

Zysk, Kenneth G., 2009 [1985]. Medicine in the Veda: Religious Healing in the Veda. Delhi: Motilal Banarsidass. 
